\title{
Corporate governance and stock liquidity dimensions: Panel evidence from pure order-driven Australian market
}

\author{
Searat Ali ${ }^{\mathrm{a}, *}$, Benjamin Liu ${ }^{\mathrm{a}}$, Jen Je Su ${ }^{\text {a }}$ \\ ${ }^{a}$ Department of Accounting, Finance and Economics, Griffith Business School, Griffith University, 170 \\ Kessels Road, Nathan QLD 4111, Australia
}

* Corresponding author. Department of Accounting, Finance and Economics, Griffith Business School, Griffith University, 170 Kessels Road, Nathan QLD 4111, Australia. Tel.: +61 737357295

E-mail addresses: searat.ali@griffithuni.edu.au (S. Ali), b.liu@griffith.edu.au (B. Liu), j.su@griffith.edu.au (J. Su). 


\title{
Corporate governance and stock liquidity dimensions: Panel evidence from pure order-driven Australian market
}

\begin{abstract}
Our newly constructed index of corporate governance quality (CGQ) provides comprehensive and robust evidence for the association between CGQ and stock liquidity in the pure order-driven Australia market. By using a large sample of 1,207 firms from 2001 to 2013, we find a significant positive relationship between CGQ and stock liquidity, suggesting that better governed firms have greatly improved stock liquidity. Specifically, we find that better governed firms have a lower trading cost, smaller price impacts of trade, and higher trading speed. Moreover, the empirical results reveal that CGQ improves stock liquidity because it is associated with higher information disclosure.
\end{abstract}

Keywords: Corporate governance; stock liquidity; trading cost; price impact; immediacy, information disclosure

JEL classification: G12, G34

\section{Introduction}

Stock liquidity continues to be a prominent research topic in the market microstructure literature, in particular since the recent global financial crisis (GFC). Handa and Schwartz (1996) stress that "Investors want three things from the markets: liquidity, liquidity and liquidity” (p. 44). Investors require compensation for holding an illiquid stock (Amihud and Mendelson, 1986) that increases the firm's cost of equity (Butler et al., 2005), and in turn affects the firm's value (Fang et al., 2009). Given that stock liquidity is crucial for both investors and firms, it is vital to investigate the antecedents of stock liquidity. ${ }^{1}$ In particular, we aim to answer two key questions: Does corporate governance quality (CGQ) determine all stock liquidity dimensions? And does CGQ affect stock liquidity through information disclosure?

Classical studies emphasize the role of internal CGQ in determining stock liquidity. For example, Coffee (1991) argues that large investors support internal governance mechanisms because such mechanisms enhance stock liquidity that in turn makes exit less costly for them. Despite such an argument, there is scant empirical evidence on the linkage between internal CGQ and stock liquidity. For instance, Chung et al. (2010) show that the CGQ improves stock liquidity in the US. These findings, however, are

\footnotetext{
1 A number of earlier studies identify stock and market characteristics (Benston and Hagerman, 1974; Branch and Freed, 1977; Tinic, 1972), and external governance environment (Bacidore and Sofianos, 2002; Brockman and Chung, 2003; Chung, 2006; Eleswarapu and Venkataraman, 2006) as a determinant of stock liquidity.
} 
limited to a short time-series (2001 to 2004) and coincide with the introduction of the Sarbanes-Oxley Act of 2002, which might have resulted in a spurious correlation between CGQ and stock liquidity. Those authors use high frequency quote-based liquidity proxies capturing trading cost and price impact dimensions, and antitakeover provisions are one of the key components of their governance index. ${ }^{2}$ This casts a doubt on the generalizability of the results from the US to other countries, where anti-takeover provisions and high frequency quote-based liquidity proxies are non-existent. Other studies on CGQ and stock liquidity are conducted in emerging markets such as Malaysia (Foo and Zain, 2010), China (Lei et al., 2013), Thailand (Prommin et al., 2014), France (Karmani and Ajina, 2012), and international markets (Chung et al., 2012). Overall, these studies suffer from small samples and limited liquidity proxies or dimensions. For instance, Prommin et al. (2014) document that better governance improves stock liquidity over time in Thailand. However, their finding does not survive in the cross-sectional setting. ${ }^{3}$ Moreover, they select only 100 large firms during a short period of time (2006 to 2009); thus, their findings may not be generalized to the wider economy.

Another important limitation of the prior studies on CGQ and stock liquidity is that these studies do not provide an empirical test of the channel through which CGQ affects stock liquidity. In theory, better CGQ increases stock liquidity by improving information transparency. In particular, better CGQ imposes more monitoring on managers and, therefore, prevents opportunistic managers from concealing and distorting information. Thus, better corporate governance improves the informational transparency of a firm and mitigates information asymmetry between insiders (e.g., managers) and outsiders (e.g., investors), as well as among outsiders. When information asymmetry is less severe, traders face fewer adverse selection problems (Glosten and Milgrom, 1985) ; hence, they provide more liquidity to stocks of well governed firms.

The importance of the stock liquidity and the limitations in the empirical literature motivate us to provide comprehensive and robust evidence on the governance-liquidity nexus. We take advantage of the recently available governance data of Australian firms through the Securities Industry Research Centre of Asia-Pacific (SIRCA) database, and use a large sample of 1,207 non-financial Australian firms (10,179 firm-year observations) over the period from 2001 to 2013. We measure corporate governance by following the Horwath report methodology more relevant to Australian firms. The Horwath report places emphasis upon the quality of a firm's internal structures and processes (e.g., board structure, and subcommittees). ${ }^{4}$ We measure stock liquidity by

\footnotetext{
2 Their governance index is based on 24 provisions; 10 of them are related to anti-takeover.

${ }^{3}$ Corporate governance provisions of large firms do not vary much. As can be seen in their summary statistics (Table 2), the governance index is 6 in the 25th percentile, 7 in the 50th percentile and 8 in the 75th percentile. This may be the reason that they have not found significant cross-sectional variation between governance quality and stock liquidity.

${ }^{4}$ This report pays special regard to the CG mechanisms that are identified as important in Australian and international CG best practice codes (US Blue Ribbon Committee Report 1999 [The Business Lawyer 1999]; Australian Securities Exchange (ASX) Principles of Good Governance and Best Practice
} 
using three main dimensions including trading cost (i.e., time-weighted quoted spread [TWQS] and zero return measure [ZERO]), price impact of trade (i.e., Amihud illiquidity estimate [ILLIQ] and liquidity ratio [AMIVEST]), and trading frequency (stock turnover [STO] and turnover-adjusted number of zero daily volumes [LM]) that are calculated by using both high and low frequency data. To test the disclosure as a channel between CGQ and stock liquidity, we mainly measure information disclosure by counting the number of documents (total, price sensitive, and non-price sensitive) released by a firm at any time over the financial year.

The pooled ordinary least squares (OLS) results reveal a significant positive linkage between CGQ and stock liquidity for Australian firms. Moreover, we discover that the improvement in stock liquidity through CGQ is related to all three dimensions of stock liquidity. In particular, the improvement is corporate governance helps a firm to reduce the trading cost and the price impact of trade, and to increase trading frequency. These findings are robust to the inclusion of the industry effect, the year effect, and the firm characteristics, such as firm size, leverage, return volatility, asset tangibility, stock price, firm age and growth opportunities. The findings of our study are economically significant as well. For example, we show that an increase in CGQ from the 25th to the 75th percentile reduces the TWQS, ILLIQ, and LM by as much as $20.89 \%$, 99.54\%, and $30.39 \%$ respectively. These findings are stronger than the findings of Chung et al. (2010) in the US (4.5\%). We also document that the relationship between CGQ and stock liquidity is unaffected by the use of high frequency or low frequency liquidity proxies. Therefore, the findings of our study provide comprehensive insights into the governance-liquidity nexus.

We then perform a variety of robustness checks to ensure that the main results are reliable. Specifically, we find that the main findings are robust to alternative estimation methods, such as a fixed effect (over time variation and omitted variable bias) and between estimators (cross-sectional variation). Further, we address the potential endogeneity bias by employing regressions based on one- and two-period lagged values of the independent variables, an instrumental variable approach i.e., two-stage least squares (2SLS), and a dynamic two-step system generalized method of moments (GMM). The results further confirm that even when the possible sources of endogeneity are controlled, better CGQ leads to greater stock liquidity.

Further, we empirically show that better governance improves stock liquidity because it is associated with a higher level of disclosure. Specifically, we find that corporate governance is positively related to disclosure, and disclosure is positively related to stock liquidity. Moreover, we document that corporate governance does not seem to be associated with a statistically significant better stock liquidity for low disclosure firms. However, corporate governance is found to sharply increase the stock liquidity of firms with high disclosure. Finally, we employ three-stage least square (3SLS) method and

Recommendations 2003 [ASX CG Council 2003]; the Organization for Economic Cooperation and Development (OECD) Report 2004). 
show that governance quality is associated with improved information environment and, hence, improves stock liquidity. These results, therefore, suggest that to improve stock liquidity, firms should adopt those governance provisions that enhance a firm's information environment.

We then perform several additional analyses and show that the main findings are robust to individual governance categories (board, audit, nomination, and remuneration quality), to the inclusion of ownership concentration, and to additional information asymmetry variables (e.g., R\&D and Big4 Audit) in the model.

We contribute to the literature in several ways. First, Australia possesses a distinctive regulatory and institutional framework that casts a doubt on the generalizability of results from the US to the Australian market (see e.g., Méndez et al., 2015; Monem, 2013). For instance, Australia has a pure order-driven trading system where public limit orders establish bid-ask prices and provide liquidity to market participants. On the contrary, the US has a quote-driven market where the designated market markers quote the bid-ask prices and supply liquidity to the market. Brown and Zhang (1997) argue that the liquidity is high in markets that allow limit orders. It is, therefore, interesting to know whether the CGQ in the pure order-driven market of Australia can explain the greater liquidity. Furthermore, compared to the US, where corporate governance (CG) is mandatory, Australian firms are subject to a 'comply or explain' regime where firms are required to disclose a reason, if they do not comply with any governance recommendation. Given such a free environment, we expect a larger variation in CG across Australian firms that may influence stock liquidity differently. Moreover, Australia has a weak market for corporate control (i.e., threat of takeover), compared to the US, which makes the internal governance mechanisms more important for Australian firms to discipline poorly performing managers (Pham et al., 2011). In addition, Australian firms have a much higher ownership concentration than US firms (La Porta et al., 1998). Since ownership concentration may act as a substitute for the internal monitoring mechanisms, CG practices are likely to vary between Australian and the US firms (Monem, 2013). Given such differences, it is imperative to investigate the role of CGQ in determining stock liquidity for Australian firms.

Second, although prior studies in Australia find an improvement in information disclosure through CGQ (Beekes and Brown, 2006; Beekes et al., 2015) and a reduction in information asymmetries through disclosure quality (Chang et al., 2008), there is no evidence showing the linkage between CGQ and stock liquidity via disclosure. We extend this literature by empirically testing disclosure as a channel through which CGQ affects stock liquidity in Australia. In particular, we examine this channel by using three estimation methods: separate regressions between CGQ and disclosure, and between disclosure and stock liquidity; separate regressions on low disclosure and high disclosure firms; and the three-stage least squares (3SLS) method to eliminate the endogeneity problem of simultaneity bias (if any) among CGQ, disclosure and stock liquidity. 
Third, prior studies on CGQ and stock liquidity include one or two dimensions of stock liquidity. ${ }^{5}$ We extend the literature by incorporating, in a single study, liquidity proxies that capture three dimensions: trading cost, price impact of trade, and immediacy. This helps to know if CGQ has a differential effect on various dimensions of stock liquidity. In addition to this, prior literature uses either high frequency quote-based or low frequency volume-based proxies of stock liquidity. ${ }^{6}$ We extend the literature by incorporating liquidity proxies that are calculated, based on both high frequency (i.e., time-weighted quoted spread) and low frequency data (e.g., Amihud illiquidity estimate, Amivest liquidity ratio and stock turnover) in a single study. The high frequency liquidity proxies are calculated from microstructure data on quotes and transactions that are not available for long time frames in most economies. However, for their calculations, low frequency liquidity proxies require daily volume and return data that are readily available in most economies for long time periods (Amihud, 2002). Hence, the use of low frequency liquidity proxies is important for the generalizability of the findings to those economies, where very little high frequency data is available.

Fourth, prior studies on CGQ and liquidity suffer from either a small cross-section or a short time-series. ${ }^{7}$ However, we cover a large panel dataset that is a large crosssectional (1,217 unique firms) and a long time series (2001 to 2013). Investigating the governance-liquidity linkage in Australia in such a period is important because of two major events that occurred. The first, the introduction of the Australian Securities Exchange CG reforms (hereafter ASX CG reforms) in 2003 enabling access to data both pre- and post-CG reforms; the second, the GFC in 2008. The sample firms come from all non-financial industries, and ages, and are heterogeneous in size and profitability. Therefore, the extended dataset allows generalizing results to the wider economy and also helps to separately investigate the relationship between CGQ and stock liquidity in both time-series (within firm) and cross-sectional (between firms) settings.

The remainder of our study proceeds as follows. Section 2 reviews literature and develops hypotheses. Section 3 presents data, sample, variable descriptions, empirical models, estimation methods, and summary statistics. In section 4, we discuss the main empirical results of the relationship between CGQ and stock liquidity dimensions. In section 5, we investigate information disclosure as a channel through which CGQ affects stock liquidity. In section 6, going beyond the composite CGQ score, we examine the effect of governance categories on stock liquidity. In section 7, we investigate the ownership concentration and the impact of CGQ on stock liquidity. Section 8 concludes the study.

\footnotetext{
${ }^{5}$ For instance, Lei et al. (2013) include only trading cost; Chung et al. (2010) include trading cost and price impact. However, Prommin et al. (2014) include price impact and immediacy.

${ }^{6}$ For example, Chung et al. (2010) and Lei et al. (2013) use high frequency proxies; Prommin et al. (2014) use low frequency proxies.

${ }^{7}$ For example, Chung et al. (2010) cover 2001 to 2004 (4 years) and 9078 observations in US; Prommin et al. (2014) cover 2006 to 2009 (4 years) and 400 observations in Thailand; Lei et al. (2013) cover 2006 to 2008 (3 years) and 3923 observations in China; Foo and Zain (2010) cover 2007 (1 year) and 481 observations.
} 


\section{Related literature and hypotheses development}

\subsection{Corporate governance and stock liquidity}

The separation of ownership and control in the modern corporation raises an information asymmetry problem between managers and investors: the managers have information that investors do not have (Jensen and Meckling, 1976). Such information asymmetry creates a moral hazard problem where managers, at the expense of outsiders, have an incentive to pursue their own interests and transfer a firm's wealth to themselves (Switzer and Wang, 2013). Self-interested and opportunistic managerial behavior can include shirking responsibility, overcompensation, consumption of perquisites and empire building. In order to mask their wealth expropriation, opportunistic managers may opt to disclose selected favourable information, resulting in more information asymmetry. In such cases, a governance mechanism is needed that can monitor managers' opportunistic behavior and guard the rights of shareholders. Fama and Jensen (1983) suggest that an efficient board that is capable of better decision making is necessary for mitigating the information asymmetry problem.

Corporate governance mechanisms (such as independence of the board and its subcommittees) are assumed to mitigate managerial incentive to distort information disclosure, and thus improve information transparency in a firm (Leuz et al., 2003). These governance mechanisms encourage self-interested managers to fully disclose reliable information to the market. Beekes and Brown (2006) and Beekes et al. (2015) empirically show that firms with better CGQ have more informative disclosure to the shareholders. Therefore, higher quality governance should reduce information asymmetry.

Empirical studies have also documented that information asymmetries between management and traders is less in firms with better disclosure policies (Chang et al., 2008; Welker, 1995). If the information asymmetry is less, it diminishes the incentive of traders to search for private information, leading to more homogeneous beliefs among traders and fewer speculative positions among informed traders (Diamond, 1985). In such circumstances, traders face less adverse selection costs (Glosten and Milgrom, 1985) and therefore provide more liquidity for stocks of firms with better governance.

Several studies have shown the empirical support of the positive relationship between corporate governance and stock liquidity around the globe-for instance, Chung et al. (2010) in the US, Foo and Zain (2010) in Malaysia, Lei et al. (2013) in China, Prommin et al. (2014) in Thailand, and Karmani and Ajina (2012) in France. However, these studies employ limited dimensions of stock liquidity and short time-series data. Moreover, empirical analysis on the disclosure as a channel between corporate governance and stock liquidity has not been shown. Finally, the findings from these studies may not be generalizable to the different Australian context-pure order driven trading system and less stringent corporate governance. Therefore, we extend the prior literature on corporate governance, information transparency and stock liquidity by 
employing three main dimensions of liquidity (trading cost, price impact, and immediacy) with the large cross-sectional and time-series data for Australian firms.

\subsection{Corporate governance and stock liquidity dimensions}

Stock liquidity is considered a 'slippery and elusive concept' (Kyle, 1985: p. 1316), for a number of transactional properties of the market including tightness (trading cost), depth (price impact) and resiliency. Tightness represents the cost of turning around a position over a short period of time. Depth refers to the ability of the market to absorb a large quantity of trade without having a large price impact. Resiliency is the speed with which the prices return to equilibrium after a large trade. ${ }^{8}$ Black (1971) suggests another stock liquidity dimension, immediacy, which represents the trading speed, that is, the speed with which buy or sell orders can be executed.

Prior stock liquidity research normally does not rely on one single proxy of stock liquidity because each proxy captures a different dimension and has its own limitations (Goyenko et al., 2009). However, the literature on governance quality and stock liquidity so far does not pay attention to the selection of the liquidity proxies/or dimensions as a critical part. For example, Lei et al. (2013) include only trading cost and Chung et al. (2010) include trading cost and price impact, measured through high frequency quote-based data. However, Prommin et al. (2014) include price impact and immediacy, calculated through low frequency volume-based data. Unlike prior literature, we incorporate all three key liquidity dimensions, calculated through either low frequency volume-based or high frequency quote-based data. This has considerable implications, since selecting an appropriate proxy for liquidity is an important issue in empirical research design (e.g., Chai et al., 2010; Goyenko et al., 2009).

Prior research suggests a time-weighted quoted spread as a direct measure of trading cost. Quoted spread represents the implicit transaction cost for market orders when a trade occurs at a quoted price with no price improvement. The bid-ask spread widens in a period of increased information asymmetry because, in such circumstances, uninformed traders shift orders away from the market and decrease the likelihood of trading with informed traders. Furthermore, Lesmond et al. (1999) argue that the price movements are less for stocks with high trading cost than for stocks with low trading cost. They argue that zero-return days occur when the transaction cost threshold does not exceed for the marginal traders, who are either informed or uninformed. If the public and private information is not sufficient to exceed the transaction cost, the informed traders are likely to minimize their desired trades, or they may choose not to trade. Hence, the price will remain unchanged from the previous day. Similarly, the liquidity traders may choose not to trade when there is a high transaction cost. As a consequence, there will be no price movement from the previous day (Lesmond et al., 1999). Building on the link between corporate governance and information asymmetry,

\footnotetext{
${ }^{8}$ Chai et al. (2010) find that the return reversal effect is small in the Australian market, due to the absence of dealers. Therefore, we do not test this dimension of stock liquidity in this study.
} 
and the link between information asymmetry and trading cost, we argue that better corporate governance reduces information asymmetry, which in turn reduces trading cost for the investors and improves stock liquidity. The hypothesis is as follows:

H1a: All else being equal, there is a negative relationship between corporate governance quality and trading cost.

Price impact of the order flow measures the absolute stock price changes with one dollar of trading volume. It is the premium that a buyer pays or the discount that a seller concedes when executing a market order that results from inventory and adverse selection costs. In particular, information asymmetry between informed and uninformed traders increases the adverse selection costs and thus the price impact of trade. Bagehot (1971) observes that the presence of better-informed traders in the market creates a problem of adverse selection that may affect the process of price formation. Prior studies, such as Huang and Stoll (1996) on informed trading, claim that the price impact of trade captures information asymmetry because trade conveys private information. A large trade by informed traders may attract other uninformed traders and create an adverse selection problem. Knowing poor corporate governance increases information asymmetry, and the price impact of trade increases with information asymmetry, it is reasonable to argue that better corporate governance improves the information environment and thus reduces the price impact of trade. The hypothesis is as follows:

H1b: All else being equal, there is a negative relationship between corporate governance quality and price impact of trade.

Bartov and Bodnar (1996) find a relationship between information asymmetry and trading volume. They explain that information asymmetry may cause a reduction in the trading volume because uninformed traders may reduce their trades in such shares. Similarly, Glosten and Milgrom (1985) claim that shares with a high trading volume have a low level of information asymmetry, since prices reveal information. Given the inverse link between trading volume and information asymmetry, we posit that better governed firms are less likely to suffer from an information asymmetry problem, and thus may experience greater immediacy or trading speed. The hypothesis is as follows:

H1c: All else being equal, there is a positive relationship between corporate governance and trading frequency.

\subsection{Governance categories and stock liquidity}

The proportion of independent directors is one of the key features of a board structure. The ASX CG Council (2003), in Principle 2.1, recommends that firms have a higher proportion of non-executive independent directors. From an agency perspective, it is argued that independent directors are more effective in monitoring and controlling the opportunistic behavior of management, and in reducing agency problems (Fama, 1980; Fama and Jensen, 1983). It is also expected that independent directors are more influential, due to their capital reputation and experience, as well as their ability to share 
and provide information and ideas from outside (Kesner and Johnson, 1990). Chen and Jaggi (2001) find that the proportion of independent directors is positively related to comprehensiveness of financial disclosure. Similarly, Ajinkya et al. (2005) show that an independent board enhances the frequency and quality of earnings forecasts by the effective monitoring of management.

CEO duality, another important aspect of a board structure, has received much attention from researchers and regulators. The ASX CG Council (2003) recommends that firms separate the roles of CEO and chair of the board (see Principle 2.3), and that an independent director should chair the board (see Principle 2.2). It is argued that chairperson independence enhances monitoring quality and thus reduces the advantages gained by withholding information, thereby improving the disclosure quality. Consistent with this argument, Haniffa and Cooke (2002) find more disclosure in firms with an independent chairman.

The ASX CG Council (2003) states, in Principle 2, that a firm should have a committed board that adequately discharges its responsibilities and duties. Since board diligence or commitment is not directly observable, the prior literature relies on the frequency of board meetings (i.e., the number of times the board meets in a year) as a proxy of board diligence (Kent and Stewart, 2008). With more frequent board meetings, the board is likely to have richer information about the firm's operating environment. This improves the board's ability to effectively exercise its monitoring role (Rutherford and Buchholtz, 2007) in mitigating the ability and incentive of a management to distort information disclosure. Foo and Zain (2010) find that board independence and board meetings improve stock liquidity. However, these findings are limited to cross-sectional data only. Based on these reasoning and limited empirical findings, we develop the following hypothesis:

H2a: Board quality, i.e., independent directors, independent chairman and board diligence, improves stock liquidity.

The ASX CG Council (2003), in Principles 2.4, 4.2, and 9.2, recommends that firms establish board subcommittees: audit, nomination, and remuneration. Harrison (1987) argues that the specific responsibilities of these committees may assist in remedying any poor attendance of the directors. Upadhyay et al. (2014) show that the board committees improve the observability of the performance of individual directors and also reduce coordination and communication problems. The role of the audit committee has received the most attention from researchers. It is regarded as an important internal control mechanism that assists in the reduction of information asymmetry between shareholders and management (Adams and Ferreira, 2007). Its interaction with external auditors assists the board to ensure that the financial statements represent a true and fair view of the firm's financial condition (Platt and Platt, 2012). The ASX CG Council (2003) also recommends that the audit committee (1) should have at least three members, all of whom are non-executive directors and a majority of whom are independent directors and (2) is chaired by an independent director, who is not the chair 
of the board. Klein (2002) argues that an audit committee composed of independent directors improves board effectiveness in monitoring management. Foo and Zain (2010) document a positive relationship between audit committee independence and stock liquidity. They recommend that future studies may consider other factors of corporate governance such as characteristics of the audit committee, remuneration and the existence of other committees. Overall, this evidence suggests that the existence and quality of board subcommittees play an effective monitoring role and are thus likely to improve informational efficiency and stock liquidity. Therefore, we develop the following hypothesis:

H2b: The presence and quality of board subcommittees (audit, nomination, and remuneration) improve stock liquidity.

\section{Data and methodology}

\subsection{Sample and data}

The initial sample of 13,500 firm-years consists of all the Australian listed firms whose CG data are available in the SIRCA during the period from 2001 to 2013. The sample period is important, since it includes the ASX CG reforms of 2003 and the GFC of 2008. Consistent with the prior literature on corporate governance and stock liquidity (see e.g., Chung et al., 2010), we exclude financial firms because of their unique financial characteristics, and their operating and regulatory environment. The financial information about the sample firms, obtained from the Morningstar DatAnalysis Premium database, is complemented by the firms' annual reports, which are available in Connect4. The data for the calculation of stock liquidity, such as stock price and trading volume, is obtained from SIRCA. The inclusion of each firm-year observation in the sample is conditioned on the availability of the following: (1) governance data; (2) financial data; and (3) liquidity data. The final sample comprises 10,179 observations on 1,207 non-financial firms across all size groups (small, medium, and large). To eliminate the undue influence of extreme values in the data, which is possibly due to spurious outliers, all continuous variables are winsorized to the 5th and 95th percentiles.

\subsection{Measures of corporate governance quality}

To capture the CG standing for each of the considered firms, we construct a CG index by following the Horwath report. Unlike the well-renowned US-based Gompers et al. (2003) governance index (i.e., G-index), which focuses on the resistance of firms to external control mechanisms, the Horwath report places emphasis on the quality of a firm's internal structures and processes. This is because, compared to the US, the market for corporate control in Australia as a mechanism for disciplining poorly performing managers is not high, which makes the role of internal CG mechanisms more important (Pham et al., 2011). The Horwath report provides composite ratings that are based on six categories: (1) board structure, (2) audit committee, (3) nomination 
committee, (4) remuneration committee, (5) external auditor independence, and (6) codes of conduct and other policy disclosures. ${ }^{9}$

Multiple aspects may limit the generalizability of the findings obtained through the Horwath report. First, the Horwath report includes the top 250 firms each year; thus, the findings may not be generalizable to medium and small firms. Second, the Horwath report is available up to 2008; therefore, the findings do not take into consideration the more recent market developments, particularly after the GFC. Third, full details of the Horwath rating system are proprietary and confidential, so we are unable to make any comments on the assignment of ranking and stars beyond the information given in the reports. In addition, two of the six categories in the Horwath report are subjective. This may limit the implications of the findings for investors because they may not be able to replicate entire Horwath ratings. Fourth, the Horwath report does not provide the category score/rating, so an important question is unexplored: which governance category really influences stock liquidity?

We address these issues by collecting an extended CG dataset, across both cross-section (small, medium, and large firms) and time-series (2001-2013), on the objective Horwath categories. These categories are based on 17 criteria. To construct the CG index, we use an equally weighted scoring methodology that has been used in extant corporate governance research (see e.g., Gompers et al., 2003). We assign the value 1 if a firm meets the particular criteria and 0 otherwise. For instance, if the majority of directors in a firm are independent we assign 1, and otherwise 0 . These individual values are then aggregated to construct a composite CG index, which ranges from 0 to 17 where 0 indicates the 'worst' governance and 17 indicates the 'best' governance. Each governance category (i.e., board, audit, nomination and remuneration quality) is the aggregate of the respective individual criteria.

\subsection{Measures of stock liquidity}

The dependent variable of our study is stock liquidity. We employ nine measures of stock liquidity, covering three dimensions: trading cost, price impact and immediacy.

\subsubsection{Tightness or trading cost}

Tightness or trading cost represents the cost of turning around a position over a short period of time. We measure tightness through time-weighted quoted spread (TWQS) and zero return measure (ZERO).

\subsubsection{Time-weighted quoted spread}

We measure TWQS as an average of the daily ratio between the time-weighted bid-ask spread (TWBAS) and the time-weighted mid-point price (TWMPP) in a financial year (Aitken and Frino, 1996; Chang et al., 2008).

\footnotetext{
${ }^{9}$ Categories 1-4 are based on objective criteria and categories 5-6 are based on subjective criteria. More details can be found at http://www.ecgi.org/codes/documents/horwath_cg_02.pdf.
} 


$$
\begin{aligned}
& \text { TWQS }_{\text {it }}=\frac{1}{D_{\text {it }}} \sum_{\text {d=1 }}^{D_{\text {iy }}} \frac{\text { TWBAS }_{\text {itd }}}{\text { TWMPP }_{\text {itd }}} \\
& \text { TWBAS }_{\text {itd }}=\frac{(\text { Ask-Bid }) \times \text { Time }_{1}+(\text { Ask }- \text { Bid }) \times \text { Time }_{2}+\cdots+(\text { Ask-Bid }) \times \text { Time }_{\mathrm{n}}}{\text { Time }_{1}+\text { Time }_{2}+\cdots+\mathrm{Time}_{\mathrm{n}}} \\
& \text { TWMPP }_{\text {itd }}=\frac{\frac{(\text { Ask+Bid })}{2} \times \text { Time }_{1}+\frac{(\text { Ask }+ \text { Bid })}{2} \times \text { Time }_{2}+\cdots+\frac{(\text { Ask }+ \text { Bid })}{2} \times \text { Time }_{\mathrm{n}}}{\text { Time }_{1}+\text { Time }_{2}+\cdots+\text { Time }_{\mathrm{n}}}
\end{aligned}
$$

where $T W B A S_{i t d}$ is the time-weighted bid-ask spread of firm $i$ on day $d$ of year $t$, $T W M P P_{i t d}$ is the time-weighted mid-point price of firm $i$ on day $d$ of year $t, D_{i t}$ is the number of days with available data for firm $i$ in year $t$. Ask and Bid are the best available ask and bid prices on the limit order book; Time $_{n}$ represents the time period that the bid-ask spread remained in existence. The higher TWQS indicates lower stock liquidity.

\subsubsection{Zero return measure}

The zero return measure (zero) is introduced by Lesmond et al. (1999). It captures the proportion of zero daily returns observed over the relevant year. Lesmond et al. (1999) show that the zero return measure is positively related to spread measures, which is consistent with the transaction cost effect on stock returns. It is calculated as follows:

$$
\text { zero }_{i t}=\frac{\mathrm{ZR}_{\mathrm{it}}}{\mathrm{TD}_{\mathrm{it}}}
$$

where $Z R_{i t}$ is the number of zero return days for firm $i$ in year $t$, and $T D_{i t}$ is the number of trading days for firm $i$ in year $t$. The higher the $Z E R O$, the lower the stock liquidity

\subsubsection{Price impact of trade}

Price impact or depth refers to the ability of the market to absorb a large quantity of trade without having a large price impact. In this study, Amihud illiquidity estimate (ILLIQ) and liquidity ratio (AMIVEST) are the two proxies of the price impact of trade.

\subsubsection{Amihud illiquidity estimate}

Given the non-availability of intraday quote data, Amihud's (2002) illiquidity estimate (ILLIQ), a low frequency proxy, is used to measure the daily price impact of the order flow. A number of empirical studies show that ILLIQ is a reliable measure of price impact (Hasbrouck, 2009) and stock liquidity (Goyenko et al., 2009; Karolyi et al., 2012; Lesmond, 2005). It is measured as the daily ratio of absolute stock return to trading volume in Australian dollars, averaged over a number of trading days in the financial year, that is, how much the absolute stock price changes with one dollar of trading volume.

$$
\text { ILLIQ }_{i t}=\frac{1}{D_{i t}} \sum_{d=1}^{D_{i t}} \frac{\left|R_{i d t}\right|}{\operatorname{VOLD~}_{\text {idt }}}
$$


where $\left|R_{i d t}\right|$ is the absolute stock return of firm $i$ on day $d$ of year $t, V O L D_{i d t}$ is the trading volume of firm $i$ on day $d$ of year $t$, and $D_{i y}$ is the number of days with available data for firm $i$ in year $t$. The higher the ILLIQ, the lower the stock liquidity.

\subsubsection{Liquidity ratio}

Liquidity ratio (AMIVEST) measures the trading volume associated with a unit change in stock price. Also known as the Amivest measure of liquidity, it is used by several studies (e.g., Amihud et al., 1997; Berkman and Eleswarapu, 1998). It is based on the view that more liquid markets are characterized with depth, breadth, and resiliency. Thus, the large trades in these markets do not have a substantial effect on the share price (Kluger and Stephan, 1997). It is measured as the sum of daily shares traded in a financial year to the sum of daily absolute stock returns in a financial year.

$$
\operatorname{AMIVEST}_{\text {it }}=\sum_{\mathrm{t}} \mathrm{VOL}_{\mathrm{it}} / \sum_{\mathrm{t}}\left|\mathrm{R}_{\mathrm{it}}\right|
$$

where $V O L_{i t}$ and $\left|R_{i t}\right|$ are, respectively, the daily share traded and the daily absolute stock returns of firm $i$ in year $t$. The higher AMIVEST suggests the higher stock liquidity.

\subsubsection{Immediacy}

Black (1971) suggests another stock liquidity dimension, immediacy, which represents the trading speed, that is, the speed with which buy or sell orders can be executed. The stock turnover (STO), turnover-adjusted number of zero daily volumes (LM), number of trades (TRADES), number of levels (LEVELS), and trading volume (VOLUME) capture the immediacy or trading speed.

\subsubsection{Stock turnover}

Stock turnover (STO) captures trading frequency: how many times a share changes owners. Datar et al. (1998) use turnover as a proxy of stock liquidity and find a significant role for stock liquidity in explaining the cross-sectional variation in stock returns. We measure turnover as the sum of daily shares traded per year to the number of shares outstanding.

$$
\mathrm{STO}_{\mathrm{it}}=\frac{\mathrm{VOL}_{\mathrm{it}}}{\mathrm{N}_{\mathrm{it}}}
$$

where $V O L_{i t}$ is the total number of shares traded for firm $i$ in a year $t$, and $N_{i t}$ is the number of outstanding shares for firm $i$ in an year $t$. Volume data for each firm is collected on a daily basis, while outstanding shares data is collected on a yearly basis. The higher the STO, the higher the stock liquidity. 


\subsubsection{Turnover-adjusted zero daily volumes}

Liu (2006) proposes the turnover-adjusted zero daily volume (LM) as a new measure of stock liquidity. Although LM places a particular focus on the trading speed, it captures multiple dimensions of liquidity. It is measured as

$$
\mathrm{LM}_{\mathrm{it}}=\left[\mathrm{NoZV}_{\mathrm{it}}+\frac{1 /\left(\text { turnover }_{i \mathrm{t}}\right)}{\text { Deflator }}\right] \mathrm{X} \frac{252}{\text { NoTD }_{\mathrm{t}}}
$$

where $\operatorname{NoZV}_{i t}$ is the number of zero daily trading volumes for firm $i$ in year $t$; turnover $_{i, t}$ is the stock turnover for firm $i$ in year $t$ obtained from Eq. (7); NoTD $D_{t}$ is the total number of trading days in year $t$; and the deflator is set to 480,000 , as suggested in Liu (2006). Multiplication by the factor $\frac{252}{N o T D_{t}}$ standardizes the number of trading days in a year as 252 and therefore, makes LM comparable over time. The higher the $L M$, the lower the stock liquidity.

The NoZV component of LM is an indicator of illiquidity - the higher the number of days with zero volume, the less frequent the trade and, therefore, the less liquid the stock. It reflects the trade continuity and potential delay in trade execution (Liu, 2006). NoZV is similar to the number of zero daily returns; therefore, LM also reflects the trading cost dimension of stock liquidity. The turnover component of LM captures the notion of how much quantity has been traded, and acts as a tiebreaker when two stocks have the same NoZV. Therefore, LM classifies stock as most liquid if it is traded frequently and has a large turnover over the relevant year.

\subsubsection{Other immediacy proxies}

Apart from the STO and LM, we also measure immediacy through the number of trades (TRADES), the number of levels (LEVELS), and the trading volume (VOLUME) (Chordia, Roll, et al., 2001; Chordia, Subrahmanyam, et al., 2001). TRADES is measured as the average number of transactions during the year. LEVELS, measured as the yearly average of the number of price levels available at a particular time in the order book, is also referred to as the depth of the order book. VOLUME is measured as the natural logarithm of the total number of shares traded (in dollars) during the year. The higher the TRADES, LEVELS and VOLUME, the higher is the stock liquidity.

\subsection{Control variables}

We include seven firm characteristics as control variables to isolate the effect of CGQ on stock liquidity: firm size, leverage, return volatility, asset tangibility, share price, firm age, and growth opportunities (Chung et al., 2010; Prommin et al., 2014). We control firm size because larger firms have more information available; they may attract much more research on their stocks and thus have less adverse selection risk (Diamond and Verrecchia, 1991). The proxy for firm size is the natural logarithm of market capitalization (ln (MC)), which is calculated as the number of shares outstanding times share price at the end of a financial year. To accurately capture the effect of tick-size- 
induced binding constraints, instead of share price, we use the reciprocal of share price (1/PRICE). Return volatility (VOLATILITY) increases the uncertainty of the cost of the holding stock, and thus more volatile stocks have a wider bid-ask spread and more information asymmetry (Ho and Stoll, 1981). We measure return volatility as the standard deviation of daily stock returns. We also control asset tangibility (TANGIBILITY) because the payoffs of tangible assets are easy to observe, and this results in low information asymmetry. The ratio of net property, plant and equipment to total assets is used as a proxy of asset tangibility. In addition, we control firm age and leverage. Firm age (AGE) is measured as the natural logarithm of the number of years since the firm's listing, and leverage (TLTA) is calculated as the book value of the total liabilities over the book value of total assets. Moreover, high growth firms may have more information asymmetry problem that leads to lower stock liquidity. We measure growth opportunities by the market to book value (MTB). Since firms in the same industry are relatively homogeneous (Alford, 1992), we use industry membership (IND) to identify firms with similar accounting methods, growth, and risk. To capture possible variation across industries, we include nine separate dummy variables for Consumer Discretionary, Consumer Staples, Energy, Health Care, Industrials, Information Technology, Materials, Telecommunication Services and Utilities. ${ }^{10}$ Finally, to capture possible variation over time, we include year effect (YR) in the model. The inclusion of year dummies will reduce the potential trending components shared by stock liquidity and corporate governance.

\subsection{Research methodology}

\subsubsection{Baseline models and estimation methods}

To test H1a (i.e., better CGQ reduces trading cost), H1b (i.e., better CGQ reduces price impact of trade), and H1c (i.e., better CGQ improves immediacy or trading frequency), we formulate the following regression equation:

$$
\begin{aligned}
& \text { SLQ }_{i, t}{\text { (Trading } \left.\text { cost }_{i, t}, \text { Price impact }_{i, t}, \text { Immediacy }_{i, t}\right)} \\
& \quad=\alpha_{0}+\beta_{1} C G Q_{i, t}+\beta_{2} \operatorname{Ln}(M C)_{i, t}+\beta_{3} \text { TLT }_{i, t}+\beta_{4} \text { VOLATILITY }_{i, t} \\
& +\beta_{5} \text { TANGIBILITY Y }_{i, t}+\beta_{6} \ln (P R I C E)_{i, t}+\beta_{7} \operatorname{Ln}(A G E)_{i, t}+\beta_{8} M T B_{i, t} \\
& +\delta R_{t}+\emptyset \operatorname{IND}_{i}+\varepsilon_{i, t}
\end{aligned}
$$

where the subscripts $i$ denotes individual firms $(i=1,2, \ldots, 1207), t$ time period $(\mathrm{t}=$ $20012002, \ldots, 2013)$, Ln natural logarithms. $\alpha, \beta, \delta$, and $\varnothing$ are parameters to be estimated. $\varepsilon_{i, t}$ is the idiosyncratic error term. The definition and details of the variables in Eq. (9) are summarized in Table 1.

\section{[Insert Table 1 here]}

First, we employ pooled ordinary least squares as a baseline method on Eq. (9) to test the time-series and cross-sectional variation in the association between CGQ and three

${ }^{10}$ We use Global Industry Classification Standard (GICS). 
dimensions of stock liquidity. The standard errors are clustered by firm to control for heteroskedasticity and within-firm correlation in the residuals (Petersen, 2009). Unlike the study by Chung et al. (2010), we also include the year and industry effects to capture the variation over time and across industries, respectively.

Second, we employ the firm fixed effect (FE) method to control for unobserved heterogeneity, due to time-unvarying omitted variables that differ across firms but are constant over time. While estimating the effects of independent variables on dependent variables, the FE method focuses on over time changes in the variables. Since this method focuses particularly on the time-series variation between CGQ and stock liquidity, and a causal relation between them can be examined using their time-series covariation, FE provides an additional insight into the empirical linkage between CGQ and the three dimensions of stock liquidity. Third, we employ a between estimators (BE) method that is based on the group means of the variables, therefore capturing only the cross-sectional variation.

\subsubsection{Endogeneity}

One may raise concern about endogeneity between CGQ and stock liquidity. It is possible that CGQ and stock liquidity are endogenously determined: not only may CGQ affect stock liquidity, but also stock liquidity may trigger changes in CGQ simultaneously (Edmans et al., 2013; Li et al., 2012). This endogeneity bias is not addressed in the study of Chung et al. (2010); however, we use three alternative model specifications to address this potential endogeneity concern. The first alternative replaces the contemporaneous values of CGQ and the other control variables with one or two years lagged values. Regressions based on contemporaneous variables are susceptible to endogeneity bias due to reverse causality, whereas regressions based on lagged values of independent variables help to control for reverse causality, and thus tend to be less susceptible to endogeneity effects.

The second alternative specification uses a two-stage least squares (2SLS) approach to further address the reverse causality issue. This method requires an instrumental variable (IV) that is strongly correlated with the endogenous variable (CGQ) but does not have a direct influence on the dependent variable (stock liquidity) (Kennedy, 2003, p. 159). Based on the literature, we consider two IVs. First, following Prommin et al. (2014) and Jiraporn et al. (2015), we use a dummy variable that is equal to 1 for the years after 2003 and 0 otherwise (the CG reform after 2003); second, following Jiraporn et al. (2011), Liu et al. (2014), Yang and Zhao (2014), and Liu et al. (2015), we use the average CGQ of all the firms in firm i's industry (excluding firm i's score). The use of CG reforms as an IV is based on the assumption that in the post reforms period (2004 to 2013), firm-level CGQ should be higher, suggesting a strong correlation between firmlevel CGQ and CG reforms. However, the CG reform should affect stock liquidity only through firm CGQ. The intuition behind using industry-average CGQ as an IV is that a firm's governance arrangements (such as board and its subcommittees) might be highly related, with the industry peers due to similar business mix and investment 
opportunities, but such industry average is unlikely to directly affect a firm's stock liquidity (Yang and Zhao, 2014).

The third alternative specification includes a lagged liquidity into main regression and estimates the augmented regression using the Arellano and Bover (1995) and Blundell and Bond (1998) dynamic two-step system GMM. ${ }^{11}$ The consistency of GMM estimation depends on two important conditions. The first is the serial independence of the residuals. The residuals in the first difference should be serially correlated (AR1) by way of construction but the residuals in the second difference should not be serially correlated (AR2). The second condition is the validity of instruments, which is tested through Hansen J-statistics of over-identifying restrictions. The Hansen J-statistics of over-identifying restrictions tests the null hypothesis of instrument validity. Compared to the 2SLS method, dynamic GMM has at least two benefits. First, it handles the endogeneity bias with internally generated instruments rather than external instruments or natural experiments that may not be readily available. Second, it explicitly models the dynamic nature of the governance-liquidity nexus by including prior year stock liquidity as one of the regressors.

\subsection{Description statistics}

Table 2 presents the descriptive statistics for the CGQ, stock liquidity, and firm characteristics in panels $\mathrm{A}, \mathrm{B}$, and $\mathrm{C}$ respectively. On average, CGQ of the sample firms is 8.456 (minimum score 1 ; maximum score 17). In terms of stock liquidity proxies, the sample mean of TWQS is 5.362, ZERO is 40.106, ILLIQ is -0.218, AMIVEST is 2.396, STO is 0.478 , LM is 4.077, \# TRADES is 148.69, \# LEVELS is 18.77 and Ln (VOL) is 17.666. In terms of firm characteristics, the sample firms have average market capitalization of AUD \$1,000 million. On average, the sample firms carry 35.5\% debt (TLTA) in their capital structure. Return volatility (VOLATILITY) and asset tangibility (TANGIBILITY) average 0.599 and 0.220 respectively. On average, the sample firms are 13.73 years old, with a share price (PRICE) of 8.406, and growth opportunities (MTB) of 2.479 .

\section{[Insert Table 2 here]}

Acknowledging the unique composition of the Australian industry sectors, we present the sample distribution, CGQ and stock liquidity by sector using GICS in Table 3. The highest number of observations is from Materials (32\%), followed by Industrials (16\%), Consumer Discretionary (14\%), and Energy (13\%). The remaining sectors (Health Care, Information Technology, Consumer Staples, Telecommunication Services and Utilities) each contribute less than the $10 \%$ to the sample. On average, CGQ is highest in Consumer Staples and lowest in Utilities. The average CGQ of Consumer Staples, Industrials, Consumer Discretionary and Health Care is higher than the sample average. However, the average CGQ of Energy, Materials, and Utilities is lower than the sample

\footnotetext{
${ }^{11}$ Please see Roodman (2009) for the detailed estimation procedure of dynamic panel data using 'xtabond2'.
} 
average. In terms of liquidity, different sectors perform differently. For instance, TWQS and ILLIQ are lowest in Consumer Staples and are highest in Information Technology, whereas LM is lowest in Health Care and highest in Consumer Discretionary. This suggests that relying on single liquidity proxy or dimension is not enough. In the last row, it is possible to observe the results of the Kruskal-Wallis test, which evidences significant differences in the variables by industry. In this sense, it is necessary to include industry dummies in the model.

\section{[Insert Table 3 here]}

\subsection{Correlation analysis}

Table 4 shows the Pearson correlation between the variables used in the analysis. In the relationship between CGQ and stock liquidity, as anticipated, CGQ has a significant negative correlation with TWQS, ZERO, Amihud ILLIQ, and LM, whereas CGQ has a statistically positive correlation with liquidity ratio (AMIVEST), stock turnover (STO), number of trades, number of levels and volume. These results suggest that stock liquidity is better in high CGQ firms. However, the correlation results here should be viewed with caution, because they do not control the other factors that affect stock liquidity. We also observe a significant correlation among alternative proxies of stock liquidity (TWQS and ZERO; ILLIQ and AMIVEST; STO, LM, TADES, LEVELS, and $V O L)$. Additionally, CGQ is positively correlated with firm size ( $\operatorname{Ln}(M C)$ ), leverage (TLTA), asset tangibility (TANGIBILITY), and firm age (Ln (AGE)), indicating that better governed firms are larger and older, and have more asset tangibility and high debt in their capital structure. On the contrary, CGQ has a negative correlation with inverse of stock price (PRICE), stock volatility (VOLATILITY), and growth opportunities $(M T B)$, implying that better governed firms are associated with lower equity risk and lower growth opportunities.

\section{[Insert Table 4 here]}

\section{Does CGQ affect stock liquidity dimensions?}

\subsection{Main results}

Table 5 presents the results of pooled OLS estimates of regression Eq. (9), when CG index is the proxy of CGQ and either trading cost (TWQS or ZERO), price impact (ILLIQ or AMIVEST), or immediacy (STO or LM) is the dimension (proxy) of stock liquidity. ${ }^{12}$ The regression Eq. (9) is well-fitted with an adjusted R-square of $54.7 \%$, 64\%, 69.7\%, 61\%, 28.3\%, and 53.5\% for TWQS, ZERO, ILLIQ, AMIVEST, STO, and LM respectively, with statistically significant $F$-statistics.

Unlike existing literature on CGQ and stock liquidity (Chung et al., 2010; Prommin et al., 2014), we are the first to demonstrate that the improvement in stock liquidity

\footnotetext{
12 We have also tested TRADES, LEVELS, and VOL as alternative liquidity measures. The results are similar; therefore we do not report them to save space in the tables. Results are available upon request.
} 
through governance quality is not restricted to one or two dimensions, but is related to all three main dimensions: trading cost, price impact, and trading frequency. In addition, we document that the relationship between CGQ and stock liquidity is unaffected by the use of high frequency (TWQS) or low frequency (e.g., ILLIQ) liquidity proxies.

Specifically, as anticipated in H1a, the coefficient on CG index is negatively significant at the $1 \%$ level for the proxies of trading cost in model 1 (TWQS) and model 2 (ZERO). This suggests that CGQ is inversely linked with the trading cost dimension of stock liquidity. As predicted in H1b, the coefficient on CG index is negative and statistically significant at the $1 \%$ level in model 3 (ILLIQ), and is positive and statistically significant at the $1 \%$ level in model 4 (AMIVEST). These results indicate that CGQ is inversely related to the price impact dimension of the stock liquidity. As expected in H1c, the CG index has a strong positive influence on the STO (model 5) and a strong negative influence on the LM (model 6). These findings show that CGQ can improve the immediacy dimension of stock liquidity. Overall, these results support the notion that better CGQ improves three dimensions of stock liquidity. Therefore, we accept H1a, H1b, and H1c.

\section{[Insert Table 5 here]}

The study gauges the economic significance of the results by calculating the marginal effect of an increase in the CG index from the 25th to the 75th percentile, corresponding to an increase in the CGQ from 5 to 12. Multiplying the change in CG index (7 points) by the coefficient on CG index (0.160 in the model 1$)$ gives a change in TWQS (trading cost) of approximately $-20.89 \%$ of the mean TWQS. Similarly, ILLIQ (price impact) and LM (immediacy) change by $-99.54 \%$ and $-30.39 \%$ in response to an increase in CG index by 7 points. Hence, these findings indicate that the trading cost and price impact could be decreased by $20.89 \%$ and $99.54 \%$ respectively, and immediacy could be increased by $30.39 \%$, with an introduction of governance mechanisms that improves the CG index from the 25th to the 75th percentile. Compared to the findings of Chung et al. (2010) in the US (4.5\%), the results are more economically significant in the less strict CG environment and pure order-driven trading system of Australia.

To investigate the within variation and to control omitted variable bias, we apply the FE method and present the results in panel A of Table 6. The regression model is wellfitted, with a reasonable adjusted R-square and statistically significant F-statistics. We again find that trading cost (TWQS and ZERO) and price impact (ILLIQ and AMIVEST) are negatively and significantly related to CGQ, while trading frequency (STO and LM) is positively and significantly related to CGQ. These results further support that better CGQ improves stock liquidity, even when the firm fixed effect is controlled. The existing literature on CGQ and stock liquidity (Chung et al., 2010; Prommin et al., 2014) shows fixed-effect regression in the short time-series $(n=4)$. However, FE may not be suitable for a relatively short time-series (Baltagi, 2008). The FE estimates, based on a relatively long time-series $(n=13)$, provide additional support to the governance-liquidity linkage. 


\section{[Insert Table 6 here]}

To gain further insight, we separately investigate the cross-sectional variation through the BE regressions. The results (see panel B, Table 6), which confirm that the CGQ is also linked to stock liquidity cross-sectionally, contrast with those of Prommin et al. (2014), who do not find significant linkage between CGQ and stock liquidity in a crosssectional setting. We argue that in their sample, based on 100 large Thai firms, most of the large firms may have similar CG and similar firm characteristics and thus may not produce cross-sectional variation in stock liquidity. The BE estimates, with a relatively large cross-section ( $i=1,207$ firms), provide additional support to the governanceliquidity linkage.

\subsection{Endogeneity}

Table 7 reports the estimated results of Eq. (9), including the CGQ and control variables of year t-1 (panel A) and year t-2 (panel B) and the stock liquidity of year t. The new estimated results are qualitatively the same as those reported in Table 5 . The regression Equation 9 with one year lagged independent variables is well-fitted, with an adjusted R-square of $54.30 \%, 61.80 \%, 69.70 \%, 61.50 \%, 26.10 \%$, and $50.40 \%$ for TWQS, ZERO, ILLIQ, AMIVEST, STO, and LM respectively, with statistically significant Fstatistics. CGQ is significantly and negatively related to trading cost and price impact, and significantly and positively related to trading frequency at lag 1 and lag 2 specifications. ${ }^{13}$ This suggests that CGQ has a power to predict stock liquidity. From these results, we conclude that the prior CGQ choices of a firm effect current stock liquidity instead of prior stock liquidity effecting current CGQ.

\section{[Insert Table 7 here]}

We report the 2SLS results in Table 8 based on two IVs (CG reform and Industry CGQ). The first-stage regression (model 1) result reveals that the coefficient on industry-average CGQ and CG reforms are positively and statistically significant. This implies that both these IVs are not weak because of their statistical power to explain firm-level CGQ. In the second-stage regressions (models 2-7), either trading cost (TWQS or ZERO), price impact (ILLIQ or AMIVEST) or immediacy (STO or LM) is the dependent variable. The coefficient on the fitted CGQ is statistically significant and confirms the earlier findings that better CGQ improves stock liquidity. ${ }^{14}$ We conclude that the results are robust to the use of the 2SLS approach.

\section{[Insert Table 8 here]}

To further address the endogeneity issue, we apply the two-step system GMM by including past stock liquidity in the main regression. The results are reported in Table 9. The diagnostics tests show that models 1-6 are well-fitted with statistically insignificant

\footnotetext{
13 Taking the lag values of only the CG index produces similar results and is not reported, for brevity.

14 The 2SLS results remain unaffected when we use alternative methods, such as, information maximum likelihood and generalized method of moments.
} 
test statistics for second-order autocorrelation in second differences (AR2) and for Hansen J-statistics of over-identifying restrictions. The interpretation of the coefficients on the CG index parallels that in Table 5. For instance, the statistically significant negative coefficients on the CG index for TWQS, ZERO, ILLIQ and LM suggest that better governance is related to greater stock liquidity. Likewise, the statistically significant positive coefficients on the CG index for AMIVEST and STO suggest that governance quality positively relates to stock liquidity. Overall, the system GMM estimates support the notion that even after controlling for unobserved heterogeneity, simultaneity, and dynamic endogeneity, better governance is associated with all the dimensions of stock liquidity in a way that is consistent with the expectation. ${ }^{15}$

\section{[Insert Table 9 here]}

Although it is difficult to completely eliminate endogeneity, the various analyses based on lagged independent variables, the 2SLS approach, and the dynamic system GMM should provide a certain degree of comfort that the relationship between CGQ and stock liquidity dimensions is not endogenously determined.

\section{Does CGQ affect stock liquidity dimensions through information disclosure?}

In this section, we explore a specific channel through which CGQ can improve stock liquidity dimensions. Since we argue in section 2 that CGQ could improve stock liquidity by improving firm disclosure, we examine whether (1) CGQ is associated with a higher disclosure (Eq. 10), and (2) a higher level of disclosure improves stock liquidity (Eq. 11).

$$
\begin{aligned}
\text { Disclosure }_{i, t} & \left(\text { TD }_{i, t},\right. \text { or PS } \\
& =\alpha_{0} \text { or NPS } \\
& =\beta_{1, t} \text { CGQ }_{i, t}+\beta_{2} \operatorname{Ln}(M C)_{i, t}+\beta_{3} \text { TLTA }_{i, t}+\beta_{4} \text { VOLATILITY }_{i, t} \\
& +\beta_{5} \text { TANGIBILITY }_{i, t}+\beta_{6} \ln (P R I C E)_{i, t}+\beta_{7} \operatorname{Ln}(A G E)_{i, t}+\beta_{8} M T B_{i, t} \\
& +\delta \text { YR }_{t}+\emptyset \text { firm }_{i}+\varepsilon_{i, t}
\end{aligned}
$$

Liquidity $_{i, t}\left(\right.$ Trading $_{\text {cost }}, t$, or Price impact $_{i, t}$, or Immediacy Im $\left._{i, t}\right)$

$$
\begin{aligned}
& =\alpha_{0}+\beta_{1} \text { Disclosure }_{i, t}+\beta_{2} \operatorname{Ln}(M C)_{i, t}+\beta_{3} \text { TLTA }_{i, t} \\
& +\beta_{4} \text { VOLATILITY }_{i, t}+\beta_{5} \text { TANGIBILITY }_{i, t}+\beta_{6} \ln (P R I C E)_{i, t} \\
& +\beta_{7} \operatorname{Ln}(A G E)_{i, t}+\beta_{8} \text { MTB }_{i, t}+\delta R_{t}+\emptyset \text { firm }_{i}+\varepsilon_{i, t}
\end{aligned}
$$

We use document count as a proxy of disclosure level. We count the number of documents released by a firm at any time over the financial year. We count each disclosure document released by a firm, regardless of whether another document was also released on the same day. The document count is the natural logarithm of the total of all documents (TD), or those classified by the ASX as price sensitive (PS) or as nonprice sensitive (NPS). Although such a measure has a limitation that it does not include

\footnotetext{
${ }^{15}$ We find similar results (unreported) when we include the two external IVs (CG reforms and Industry CGQ) with the internal IVs in the GMM.
} 
intermediate sources such as analyst reports ${ }^{16}$ or press items, its advantage is that it captures the information emanating from the firm itself, directed to the stock market (Beekes and Brown, 2006; Beekes et al., 2015).

The descriptive statistics (untabulated) indicate that, on average, sample firms released 48 total documents, 13 price sensitive documents, and 35 non-price sensitive documents per year during the 13 years. The correlation analysis (untabulated) provides a strong positive bi-variate relationship between CGQ and disclosure, and between disclosure and stock liquidity. Table 10 reports the multivariate results between CGQ and disclosure in panel A, and between disclosure and stock liquidity dimensions in panel B. To mitigate unobserved heterogeneity, we estimate these relationships by using firm fixed effect regressions. As shown in panel A and panel B of Table 10, after controlling firm characteristics and year effects, we find that CGQ is positively related to disclosure (TD, PS, and NPS), and disclosure is positively related to stock liquidity dimensions (trading cost, price impact and immediacy). Overall, these results indicate that governance quality is associated with an improved information environment and, hence, reduces stock liquidity risk.

\section{[Insert Table 10 here]}

Furthermore, we use a split sample strategy to check if CGQ has a stronger effect on stock liquidity for the firms that disclose more information. We split the sample into firms with high disclosure and firms with low disclosure using TD. We classify a firm in a low disclosure category if TD is in the 25th percentile (Q1) and in a high disclosure category if TD is in the 75th percentile (Q4). Table 11 presents the fixed effect regression results. For low disclosure firms, CGQ does not seem to be associated with a statistically significant better stock liquidity. On the other hand, CGQ is found to sharply increase the stock liquidity of firms with high disclosure. These findings are robust to alternative dimensions of stock liquidity. We also use alternative proxies of disclosure (PS and NPS), and alternative classification method (sample median). The results (untabulated) are similar to those reported in Table 11. Thus, we confirm that CGQ improves stock liquidity through an improved information environment of a firm.

\section{[Insert Table 11 here]}

Finally, a stream of literature (e.g., Edmans et al., 2013) provides evidence on the reverse effect of stock liquidity on governance. Although such literature measures governance through ownership variables (blockholders) that differ from our governance proxy (board and subcommittees), we use the three-stage least squares (3SLS) method to eliminate the endogeneity problem from simultaneity bias (if any) among CGQ, disclosure and stock liquidity. We endogenize CGQ and disclosure, given existing literature (Beekes et al., 2015; Haß et al., 2014; Monem, 2013) on their determinants,

\footnotetext{
${ }^{16}$ Some studies consider analyst coverage as a monitoring mechanism to scrutinize managerial behavior in distorting information. These studies show that stock illiquidity increases with an exogenous loss of analyst coverage (see e.g., Chen et al., 2015).
} 
by developing two regression equations, Eq. (12) and Eq. (13), for CGQ and disclosure, respectively:

$$
\begin{aligned}
& \text { Disclosure }_{i, t}\left(T D_{i, t}\right) \\
& =\alpha+\beta_{1} \text { Liquidity }_{i, t}+\beta_{1} C G Q_{i, t}+\beta_{2} \operatorname{Ln}(M C)_{i, t}+\beta_{3} R O A_{i, t} \\
& +\beta_{4} \text { LOSS }_{i, t}+\beta_{5} \text { TLTA }_{i, t}+\beta_{6} \operatorname{lnMTB}_{i, t}+\beta_{7} \text { VOLATILITY }_{i, t} \\
& +\beta_{8} P R I C E_{i, t}+\beta_{8} I F R S_{t}+\varnothing I N D_{i}+\varepsilon_{i, t} \\
& C_{G} Q_{i, t}=\alpha+\beta_{1} \text { Disclosure }_{i, t}+\beta_{2} \text { Liquidity }_{i, t}+\beta_{3} \operatorname{Ln}(M C)_{i, t}+\beta_{4} R O A_{i, t} \\
& +\beta_{5} T L T A_{i, t}+\beta_{6} \ln A G E_{i, t}+\beta_{7} \operatorname{Ln}(A G E)^{2}{ }_{i, t}+\beta_{8} M T B_{i, t} \\
& +\beta_{8} \text { TOP } 20_{i, t}+\beta_{8} R E F O R M_{t}+\emptyset I N D_{i}+\varepsilon_{i, t}
\end{aligned}
$$

The definition of variables (except for ROA, LOSS, IFRS, TOP20 and REFORM) remains the same as summarized in Table 1. ROA is the net income over total assets; LOSS is a dummy variable for the year in which net income is negative; International Financial Reporting Standards (IFRS) is equal to 1 for the year 2006 and afterwards, and 0 otherwise; TOP20 is the percentage of outstanding shares held by top twenty shareholders; REFORM is equal to 1 for the year 2004 and afterwards, and 0 otherwise. The three equations, Eq. (9) with the inclusion of disclosure, Eq. (12) and Eq. (13), are solved as a system of simultaneous equations using the 3SLS method; results are reported in Table 12. We do not report the control variables for brevity. Panel A of Table 12 shows the effect of CGQ on stock liquidity. Even with direct control of endogeneity with 3SLS, the findings remain the same i.e., better CGQ improves stock liquidity dimensions (trading cost, price impact, and immediacy).

\section{[Insert Table 12 here]}

\section{Robustness checks: Does CGQ affect stock liquidity dimensions?}

\subsection{Governance categories}

The empirical evidence so far demonstrates a robust positive association between CGQ and stock liquidity dimensions. The CG index is based on four governance categories: (1) board structure, (2) audit committee, (3) remuneration committee, and (4) nomination committee. In this section, we aim to understand which specific CGQ categories drive the results. Since some of the CGQ categories are correlated, we run separate regressions for each category to avoid multicollinearity problems. The fixed effect regression results, reported in Table 13, show that all the governance categories are significantly related to the three dimensions of stock liquidity. However, the large coefficient on board quality than on those of the other three categories should be noted. This is consistent with the notion that board quality (proportion of independent directors, CEO duality, and board meetings) is directly related to management control, thus preventing them from distorting information. Overall, the evidence suggests the 
relationship between CGQ and stock liquidity is not driven by a few governance categories. Therefore, we accept $\mathrm{H} 2 \mathrm{a}$ and $2 \mathrm{~b}$.

\section{[Insert Table 13 here]}

In addition to the governance categories, we also investigate the relationship between individual governance variables and stock liquidity. To do so, we first omit the highly correlated variables from each governance category and we run separate fixed-effect regressions for the individual variables of board, audit, remuneration, and nomination. The results are reported in Table 14. We find that two of the board quality variables (proportion of independent directors; number of board meetings) significantly reduce liquidity risk. Further to this, the presence and quality (independence, size, and meetings) of an audit committee significantly increase stock liquidity. The presence and quality (independence) of nomination and remunerations committee also improve stock liquidity. Although we find significant relations between individual governance variables and stock liquidity, such a relationship seems a little sensitive to the choice of liquidity proxies.

\section{[Insert Table 14 here]}

\subsection{Ownership structure}

We further check the robustness of the results by including ownership concentration in the model. A number of prior empirical studies show that the concentrated ownership structure plays an important role in shaping stock liquidity. Theoretically, (see e.g., Bolton and Thadden, 1998; Maug, 1998), concentrated ownership may influence stock liquidity through two key mechanisms: the informed-trading effect and the tradingactivity effect. The informed-trading effect indicates that since large shareholders have an incentive to monitor the operations of the firms, they have access to private, valuerelevant information and they may trade on this information to extract private benefits, thus increasing adverse selection costs and reducing stock liquidity (Heflin and Shaw, 2000). The trading-activity effect argues that high ownership concentration is inversely related to trading volume and continuity of order flow because large shareholders trade with lower frequency, leading to wider spreads and lower depth (Kothare, 1997). Both these effects suggest the inverse relationship of ownership concentration with stock liquidity (Chu et al., 2015).

Further to this, ownership concentration may be related to internal governance practices. Since ownership concentration permits close monitoring of a firm's management, it may reduce the demand for alternative monitoring mechanisms (e.g., proportion of independent directors and separation of CEO from board chair). Consistent with this argument, Monem (2013) finds that high ownership concentration decreases board independence and increases CEO duality. Given these evidences, it is interesting to include ownership concentration variables in the model and examine if the CGQ and stock liquidity survives in the presence of ownership concentration. 
We consider four ownership concentration variables; namely, the percentage of shares held by the top twenty shareholders (Top 20), by substantial shareholders (block), and by the chief executive officer (CEO), as well as the presence of directors with substantial shareholdings (Directors). We collect this data from SIRCA. Based on these four variables, we construct an ownership concentration index (OC index). We assign 1 if the Top 20, block and CEO shareholdings are higher than the sample median and 0 otherwise and assigns 1 if one or more of the directors is the substantial shareholders of the firm and 0 otherwise. The OC index ranges from 0 to 4 , where 0 indicating the lowest concentration and 4 the highest concentration.

Table 15 presents the results between CGQ, ownership concentration and stock liquidity. As expected and shown in Table 15, the OC index has a significant negative influence on stock liquidity. Specifically, we find that high ownership concentration is associated with higher trading cost, higher price impact of trade, and low trading frequency. Importantly, the coefficients on CGQ remain significant even after controlling for ownership concentration. This again confirms the robustness of the results on the relationships between CGQ and the three dimensions of stock liquidity.

\section{[Insert Table 15 here]}

\subsection{Information asymmetry}

Since information asymmetry is an important factor that affects stock liquidity, we further check the robustness of our main results by including three additional variables to capture the extent of information asymmetry. First, we look into the quality of the firm's auditor (Jiang et al., 2017). Good auditors reduce both intentional and unintentional measurement errors in historical earnings, leading to transparent financial statements (e.g., Becker et al., 1998), and thus decrease information asymmetry between insiders and outsiders. Second, we focus on the R\&D intensity to capture the level of information asymmetry in a firm (Cai et al., 2015). Prior literature suggests that insider trading gains are substantially greater in $R \& D$ intensive firms than non-R\&D intensive firms; therefore, $R \& D$ is considered a major factor in increasing information asymmetry (Aboody and Lev, 2000). Moreover, high R\&D intensity may increase asymmetric information problems because it is difficult to observe the payoffs from R\&D (Chung et al., 2010). Finally, we employ CEO shareholdings to gauge the degree of information asymmetry. Managers (i.e., CEO) constitute a subgroup of informed traders for three reasons: 1) They naturally have access to insider information, 2) they own a considerable amount of shares in the company, and 3) they trade in their own firms' stocks (Bharath et al., 2009). Furthermore, it is argued that CEOs who own greater proportions of the firm's stock are more powerful, and powerful CEOs lack opinion diversification and compromise less with other executives of the firms. Consequently, powerful CEOs are likely to be associated with information asymmetry (Adams et al., 2005) and poor stock liquidity.

Empirically, we use Big4, $R \& D$, and CEOSh to proxy for information asymmetry. Big4 is a dummy variable that takes a value ' 1 ' if a firm is audited by a Big 4 Audit firm and 
' 0 ' otherwise. The data on Big4 is obtained from SIRCA. ${ }^{17} R \& D$ is a ratio of R\&D expenditure divided by annual sales. The frequency of missing observations is high for the $R \& D$ expenditure because many firms do not report $R \& D$ expenditure. To maximize data utilization, consistent with prior studies (e.g., Chung et al., 2010), we assume that a firm has zero R\&D expenditure if its $R \& D$ expenditure is not reported in the OSIRIS database. CEOSh is a percentage of the firm's outstanding shares held by the CEO. The data on CEOSh is obtained from SIRCA. We include these factors in our baseline regression Eq. (9).

Table 16 presents the firm fixed effect regression results. We find that CGQ is negatively and significantly linked to trading cost (TWQS and ZERO) and price impact (ILLIQ and AMIVEST), while CGQ is positively and significantly associated to trading frequency (STO and LM). These results confirm that even when the additional variables related to information asymmetry are controlled, CGQ has a strong positive impact all stock liquidity dimensions.

\section{[Insert Table 16 here]}

\section{Robustness analyses: Does CGQ affect stock liquidity dimensions through information disclosure?}

\subsection{Subgroup analysis based on information asymmetry}

To strengthen the subsample analysis as reported in Table 11, we explore whether the CGQ effect on stock liquidity is different among high information asymmetry firms over those with low information asymmetry. We classify a firm into low information asymmetry group based on Big4, R\&D, and CEOSh. Specifically, we consider a firm in a low information asymmetry category, if a firm avails the auditing service from Big4 audit firm; a firm has zero R\&D expenditure, and a firm has low CEO shareholdings (25th percentile). Table 17 presents the fixed effect regression results in panel A for $B I G 4$, in panel $\mathrm{B}$ for $R \& D$, and in panel C for CEOSh. For brevity, we report results for only three liquidity proxies (TWQS, ILLIQ, and LM). A lower value of these liquidity proxies indicates greater stock liquidity. Our results indicate that the positive effect of CGQ on stock liquidity dimensions is much stronger and significant for the firms with low information asymmetry (Columns 1, 3, and 5). On the contrary, we find less significantly positive impact of CGQ on stock liquidity for the firms with high information asymmetry (Columns 2, 4, and 6). From these results, we infer that if the firm wants to improve stock liquidity then it should adopt the governance provisions that alleviate the information asymmetry problems.

\section{[Insert Table 17 here]}

\footnotetext{
17 We have also used the available observations of analyst coverage from the Bloomberg and results are robust.
} 


\subsection{Alternative proxy for information disclosure}

In section 5, we find that information disclosure is a channel through which CGQ affects stock liquidity. To make this result more robust, instead of using document count, we employ an alternative proxy for information disclosure - timeliness of price discovery (Beekes and Brown, 2006; Beekes et al., 2015). This measure has its origins in the seminal work of Ball and Brown (1968) who stated that annual financial statements are not a timely source of earnings-related information because most of the value-relevant component of earnings (85\% to 90\%) has already been captured by timelier media. This metric captures how accurately a firm's share price $\left(P_{t}\right)$, observed at daily intervals from day-250 until day-1, approximates its terminal value $\left(P_{0}\right)$, which is the share price 10 days after the release of a firm's preliminary financial statement (PFS). Specifically, we measure timeliness of price discovery as:

TIMELINESS $=\frac{\left(\left(\sum_{t=-250}^{t=-1}\left|\ln \left(P_{0}\right)-\ln \left(P_{t}\right)\right|\right)-0.5\right)}{250}$

where $P_{t}$ is daily market-adjusted share price, $P_{0}$ is the price 10 days after the PFS announcement date, and the constant $-0.5 / 250$ is an adjustment made to recognize the flow of information that is reflected in returns over the trading day.

Timeliness metric captures how much value relevant information is already known from other sources prior to the PFS announcement. If a firm releases value relevant information on a timely basis, the information is incorporated into share price quickly, and then the metric will have a value closer to zero. Therefore, the smaller it takes a firm's share price to converge to its terminal price, the smaller the value of TIMELINESS.

Table 18 reports the results between CGQ and timeliness in panel A and between timeliness and stock liquidity dimensions in panel B. The results indicate that CGQ is significantly and negatively associated with timeliness, suggesting that value relevant information is priced rapidly when the firm has better governance quality. Furthermore, we document that timeliness is significantly and positively associated with stock illiquidity, implying that the longer it takes to incorporate value relevant information, the poorer is the stock liquidity. Overall, these results indicate that governance quality improves stock liquidity because it is associated with an efficient information environment of a firm.

\section{[Insert Table 18 here]}

\section{Conclusion}

We contribute to the literature by providing comprehensive and updated evidence on the linkage between governance quality and stock liquidity. Compared to the more stringent governance and quote-driven market of the US (Chung et al., 2010), we provide new evidence on the linkage between CGQ and stock liquidity in the less stringent 
governance and pure order-driven market of Australia. In contrast to Chung et al. (2010), we construct a CG index that is based purely on internal governance quality and is more relevant to Australian firms, and uses stock liquidity proxies that cover all three dimensions of liquidity: trading cost (time-weighted quoted spread and zero return measure), price impact of trade (Amihud illiquidity estimate and liquidity ratio), and immediacy (stock turnover and turnover adjusted zero volume days). These proxies are calculated by using high and low frequency quote-, volume- and price-based data. In addition, unlike Chung et al. (2010), we cope with reverse causality by using lagged variables, 2SLS and dynamic system GMM.

Based on these improvements in methodology, we find a stronger positive influence of CGQ on all stock liquidity dimensions in Australia over the period from 2001 to 2013. Specifically, the results indicate that firms can reduce trading cost and price impact of trade, and can increase trading frequency, with an improvement in corporate governance. These findings are robust to different proxies of stock liquidity dimensions, to alternative estimation methods (pooled OLS, FE, and BE), to endogeneity bias, to governance categories (board, audit, nomination, and remuneration), to the ownership concentration and information asymmetry variables.

Explicitly, these findings look similar to the findings of Chung et al. (2010); however, we provide several new insights. First, compared to the US results, the Australian results have a stronger economic significance. These findings indicate that Australian firms can reduce the quoted spread by $20.89 \%$ (4.5\% in the US) with an increase in governance quality from 25 th to 75 th percentiles. Second, these results are generalizable to markets where high frequency liquidity data and anti-takeover provisions are not readily available. Finally, we are the first to empirically show that better governance improves stock liquidity because it is associated with a higher level of disclosure both in terms of document counts and timeliness of price discovery.

The overall findings suggest that governance quality is an important determinant of stock liquidity. Given such findings, one of the important practical implications of these results is that investors and firms may wish to monitor governance mechanisms more closely in order to devise sound trading strategies and corporate governance structure, respectively. From a regulatory perspective, as corporate governance improves stock liquidity through information disclosure, this gives empirical support to the regulators to simultaneously design appropriate governance recommendations, disclosure policies and trading regulations.

\section{Acknowledgement}

We would like to thank the editor (Hamid Beladi) and the anonymous reviewer for their constructive comments and valuable suggestions on earlier versions of the paper. We acknowledge that in the very formative stages of developing this research idea, our thinking was greatly assisted by completing the 'pitching template' created by (Faff, 2015a, 2015b). As background, refer to Corporate governance and stock liquidity in Australia: A pitch (Ali, 2016). We are grateful to David Michayluk, Robert Faff, Petko 
Kalev, Sue Wright, Gary Monroe, Steve Easton, and the participants at the SIRCA's pitching research symposium for their helpful suggestions. We are thankful to Robert Faff for giving his valuable feedback. We also thank Tao Chen, Geeta Duppati and other participants at the 23rd Securities and Financial Market (SFM) conference in 2015 and Accounting and Finance Association of Australia and New Zealand (AFAANZ) in 2016 for their valuable suggestions. The study won Best Paper Award in the Corporate Governance Stream at 2016 AFAANZ conference. We thank Griffith University Postgraduate Students Association (GUPSA) and Jennifer Beale for their English editing service and Griffith Graduate Research School (GGRS) for the conference travel grant. We thank SIRCA for assisting us with access to the corporate governance and stock liquidity dataset.

\section{References}

Aboody, D., Lev, B., 2000. Information asymmetry, R\&D, and insider gains. The journal of finance. 55 (6), 2747-2766.

Adams, R. B., Almeida, H., Ferreira, D., 2005. Powerful CEOs and their impact on corporate performance. Review of Financial Studies. 18 (4), 1403-1432.

Adams, R. B., Ferreira, D., 2007. A theory of friendly boards. The journal of finance. 62 (1), 217-250.

Aitken, M., Frino, A., 1996. The determinants of market bid ask spreads on the australian stock exchange: Cross-sectional analysis. Accounting \& Finance. 36 (1), 51-63.

Ajinkya, B., Bhojraj, S., Sengupta, P., 2005. The association between outside directors, institutional investors and the properties of management earnings forecasts. Journal of accounting research. 43 (3), 343-376.

Alford, A. W., 1992. The effect of the set of comparable firms on the accuracy of the price-earnings valuation method. Journal of accounting research. 30 (1), 94108.

Ali, S., 2016. Corporate governance and stock liquidity in Australia: A pitch. Journal of Accounting and Management Information System, forthcoming.

Amihud, Y., 2002. Illiquidity and stock returns: Cross-section and time-series effects. Journal of Financial Markets. 5 (1), 31-56.

Amihud, Y., Mendelson, H., 1986. Asset pricing and the bid-ask spread. Journal of financial Economics. 17 (2), 223-249.

Amihud, Y., Mendelson, H., Lauterbach, B., 1997. Market microstructure and securities values: Evidence from the tel aviv stock exchange. Journal of financial Economics. 45 (3), 365-390.

Arellano, M., Bover, O., 1995. Another look at the instrumental variable estimation of error-components models. Journal of econometrics. 68 (1), 29-51.

Bacidore, J. M., Sofianos, G., 2002. Liquidity provision and specialist trading in nyselisted non-us stocks. Journal of financial Economics. 63 (1), 133-158.

Bagehot, W., 1971. The only game in town. Financial Analysts Journal. 27 (2), 12-14. 
Ball, R., Brown, P., 1968. An empirical evaluation of accounting income numbers. Journal of accounting research. 6 (2), 159-178.

Baltagi, B. H. 2008. Econometric analysis of panel data, 4th ed, John Wiley \& Sons.

Bartov, E., Bodnar, G. M., 1996. Alternative accounting methods, information asymmetry and liquidity: Theory and evidence. Accounting Review. 71 (3), 397-418.

Beekes, W., Brown, P., 2006. Do better-governed australian firms make more informative disclosures? Journal of Business Finance \& Accounting. 33 (3-4), 422-450.

Beekes, W., Brown, P., Zhang, Q., 2015. Corporate governance and the informativeness of disclosures in Australia: A re-examination. Accounting \& Finance. 55 (4), 931-963.

Benston, G. J., Hagerman, R. L., 1974. Determinants of bid-asked spreads in the overthe-counter market. Journal of Financial Economics. 1 (4), 353-364.

Berkman, H., Eleswarapu, V. R., 1998. Short-term traders and liquidity: A test using Bombay Stock Exchange data. Journal of financial Economics. 47 (3), 339-355.

Bharath, S. T., Pasquariello, P., Wu, G., 2009. Does asymmetric information drive capital structure decisions? Review of Financial Studies. 22 (8), 3211-3243.

Black, F., 1971. Toward a fully automated stock exchange, part I. Financial Analysts Journal. 27 (4), 28-35.

Blundell, R., Bond, S., 1998. Initial conditions and moment restrictions in dynamic panel data models. Journal of econometrics. 87 (1), 115-143.

Bolton, P., Thadden, V., 1998. Blocks, liquidity, and corporate control. The journal of finance. 53 (1), 1-25.

Branch, B., Freed, W., 1977. Bid-asked spreads on the amex and the big board. The journal of finance. 32 (1), 159-163.

Brockman, P., Chung, D. Y., 2003. Investor protection and firm liquidity. The journal of finance. 58 (2), 921-938.

Brown, D. P., Zhang, Z. M., 1997. Market orders and market efficiency. Journal of Finance. 52 (1), 277-308.

Butler, A. W., Grullon, G., Weston, J. P., 2005. Stock market liquidity and the cost of issuing equity. Journal of Financial and Quantitative Analysis. 40 (02), 331348.

Cai, J., Liu, Y., Qian, Y., Yu, M., 2015. Information asymmetry and corporate governance. Quarterly Journal of Finance. 5 (03). doi: http://dx.doi.org/10.1142/S2010139215500147

Chai, D., Faff, R., Gharghori, P., 2010. New evidence on the relation between stock liquidity and measures of trading activity. International Review of Financial Analysis. 19 (3), 181-192.

Chang, M., D'Anna, G., Watson, I., Wee, M., 2008. Does disclosure quality via investor relations affect information asymmetry? Australian Journal of Management. 33 (2), 375-390. 
Chen, C. J., Jaggi, B., 2001. Association between independent non-executive directors, family control and financial disclosures in Hong Kong. Journal of Accounting and Public Policy. 19 (4), 285-310.

Chen, T., Harford, J., Lin, C., 2015. Do analysts matter for governance? Evidence from natural experiments. Journal of financial Economics. 115 (2), 383-410.

Chordia, T., Roll, R., Subrahmanyam, A., 2001. Market liquidity and trading activity. The journal of finance. 56 (2), 501-530.

Chordia, T., Subrahmanyam, A., Anshuman, V. R., 2001. Trading activity and expected stock returns. Journal of financial Economics. 59 (1), 3-32.

Chu, X., Liu, Q., Tian, G. G., 2015. Does control-ownership divergence impair market liquidity in an emerging market? Evidence from China. Accounting \& Finance. 55 (3), 881-910.

Chung, H., 2006. Investor protection and the liquidity of cross-listed securities: Evidence from the ADR market. Journal of Banking \& Finance. 30 (5), 14851505.

Chung, K. H., Elder, J., Kim, J.-C., 2010. Corporate governance and liquidity. Journal of Financial and Quantitative Analysis. 45 (2), 265-291.

Chung, K. H., Kim, J. S., Park, K., Sung, T., 2012. Corporate governance, legal system, and stock market liquidity: evidence around the world. Asia-Pacific Journal of Financial Studies. 41 (6), 686-703.

Coffee, J. C., 1991. Liquidity versus control: The institutional investor as corporate monitor. Columbia Law Review. 91 (6), 1277-1368.

Datar, V. T., Naik, N. Y., Radcliffe, R., 1998. Liquidity and stock returns: An alternative test. Journal of Financial Markets. 1 (2), 203-219.

Diamond, D. W., 1985. Optimal release of information by firms. The journal of finance. 40 (4), 1071-1094.

Diamond, D. W., Verrecchia, R. E., 1991. Disclosure, liquidity, and the cost of capital. The journal of finance. 46 (4), 1325-1359.

Edmans, A., Fang, V. W., Zur, E., 2013. The effect of liquidity on governance. Review of Financial Studies. 26 (6), 1443-1482.

Eleswarapu, V. R., Venkataraman, K., 2006. The impact of legal and political institutions on equity trading costs: A cross-country analysis. Review of Financial Studies. 19 (3), 1081-1111.

Faff, R. W., 2015a. Pitching research. Retrieved from http://ssrn.com/abstract=2462059.

Faff, R. W., 2015b. A simple template for pitching research. Accounting \& Finance. 55 (2), 311-336.

Fama, E. F., 1980. Agency problems and the theory of the firm. The journal of political economy. 88 (2), 288-307.

Fama, E. F., Jensen, M. C., 1983. Separation of ownership and control. The Journal of Law \& Economics. 26 (2), 301-325.

Fang, V. W., Noe, T. H., Tice, S., 2009. Stock market liquidity and firm value. Journal of financial Economics. 94 (1), 150-169. 
Foo, Y.-B., Zain, M. M., 2010. Board independence, board diligence and liquidity in Malaysia: A research note. Journal of Contemporary Accounting \& Economics. 6 (2), 92-100.

Glosten, L. R., Milgrom, P. R., 1985. Bid, ask and transaction prices in a specialist market with heterogeneously informed traders. Journal of financial Economics. 14 (1), 71-100.

Gompers, P., Ishii, J., Metrick, A., 2003. Corporate governance and equity prices. The Quarterly Journal of Economics. 118 (1), 107-156.

Goyenko, R. Y., Holden, C. W., Trzcinka, C. A., 2009. Do liquidity measures measure liquidity? Journal of financial Economics. 92 (2), 153-181.

Handa, P., Schwartz, R. A., 1996. How best to supply liquidity to a securities market. The Journal of Portfolio Management. 22 (2), 44-51.

Haniffa, R. M., Cooke, T. E., 2002. Culture, corporate governance and disclosure in Malaysian corporations. Abacus. 38 (3), 317-349.

Harrison, J. R., 1987. The strategic use of corporate board committees. California Management Review. 30 (1), 109-125.

Hasbrouck, J., 2009. Trading costs and returns for US equities: Estimating effective costs from daily data. The journal of finance. 64 (3), 1445-1477.

Haß, L. H., Vergauwe, S., Zhang, Q., 2014. Corporate governance and the information environment: Evidence from Chinese stock markets. International Review of Financial Analysis. 36, 106-119.

Heflin, F., Shaw, K. W., 2000. Blockholder ownership and market liquidity. Journal of Financial and Quantitative Analysis. 35 (04), 621-633.

Ho, T., Stoll, H. R., 1981. Optimal dealer pricing under transactions and return uncertainty. Journal of financial Economics. 9 (1), 47-73.

Huang, R. D., Stoll, H. R., 1996. Dealer versus auction markets: A paired comparison of execution costs on nasdaq and the nyse. Journal of financial Economics. 41 (3), 313-357.

Jensen, M. C., Meckling, W. H., 1976. Theory of the firm: Managerial behavior, agency costs and ownership structure. Journal of financial Economics. 3 (4), 305-360.

Jiang, F., Ma, Y., Shi, B., 2017. Stock liquidity and dividend payouts. Journal of Corporate Finance. 42 295-314.

Jiraporn, P., Chatjuthamard, P., Tong, S., Kim, Y. S., 2015. Does corporate governance influence corporate risk-taking? Evidence from the Institutional Shareholders Services (ISS). Finance Research Letters. 13, 105-112.

Jiraporn, P., Kim, J. C., Kim, Y. S., 2011. Dividend payouts and corporate governance quality: An empirical investigation. Financial Review. 46 (2), 251-279.

Karmani, M., Ajina, A., 2012. Market stock liquidity and corporate governance. Paper presented at the 29th International Conference of the French Finance Association (AFFI), Strasbourg, France.

Karolyi, G. A., Lee, K.-H., Van Dijk, M. A., 2012. Understanding commonality in liquidity around the world. Journal of financial Economics. 105 (1), 82-112. 
Kennedy, P. 2003. A guide to econometrics, 5th ed, Blackwell Publishing, Oxford, UK.

Kent, P., Stewart, J., 2008. Corporate governance and disclosures on the transition to international financial reporting standards. Accounting \& Finance. 48 (4), 649671.

Kesner, I. F., Johnson, R. B., 1990. An investigation of the relationship between board composition and stockholder suits. Strategic Management Journal. 11 (4), 327336.

Klein, A., 2002. Audit committee, board of director characteristics, and earnings management. Journal of Accounting and Economics. 33 (3), 375-400.

Kluger, B. D., Stephan, J., 1997. Alternative liquidity measures and stock returns. Review of Quantitative Finance and Accounting. 8 (1), 19-36.

Kothare, M., 1997. The effects of equity issues on ownership structure and stock liquidity: A comparison of rights and public offerings. Journal of financial Economics. 43 (1), 131-148.

Kyle, A. S., 1985. Continuous auctions and insider trading. Econometrica: Journal of the Econometric Society. 53 (6), 1315-1335.

La Porta, R., Lopez-de-Silanes, F., Shleifer, A., Vishny, R., 1998. Law and finance. Journal of Political Economy. 106 (6), 1113-1155.

Lei, Q., Lin, B., Wei, M., 2013. Types of agency cost, corporate governance and liquidity. Journal of Accounting and Public Policy. 32 (3), 147-172.

Lesmond, D. A., 2005. Liquidity of emerging markets. Journal of financial Economics. 77 (2), 411-452.

Lesmond, D. A., Ogden, J. P., Trzcinka, C. A., 1999. A new estimate of transaction costs. Review of Financial Studies. 12 (5), 1113-1141.

Leuz, C., Nanda, D., Wysocki, P. D., 2003. Earnings management and investor protection: An international comparison. Journal of financial Economics. 69 (3), 505-527.

Li, W.-X., Chen, C. C.-S., French, J. J., 2012. The relationship between liquidity, corporate governance, and firm valuation: Evidence from Russia. Emerging Markets Review. 13 (4), 465-477.

Liu, W., 2006. A liquidity-augmented capital asset pricing model. Journal of financial Economics. 82 (3), 631-671.

Liu, Y., Miletkov, M. K., Wei, Z., Yang, T., 2015. Board independence and firm performance in China. Journal of Corporate Finance. 30 (1), 223-244.

Liu, Y., Wei, Z., Xie, F., 2014. Do women directors improve firm performance in china? Journal of Corporate Finance. 28 (1), 169-184.

Maug, E., 1998. Large shareholders as monitors: is there a trade-off between liquidity and control? The journal of finance. 53 (1), 65-98.

Méndez, C. F., Pathan, S., García, R. A., 2015. Monitoring capabilities of busy and overlap directors: Evidence from Australia. Pacific-Basin Finance Journal. 35, 444-469. 
Monem, R. M., 2013. Determinants of board structure: Evidence from Australia. Journal of Contemporary Accounting \& Economics. 9 (1), 33-49.

Petersen, M. A., 2009. Estimating standard errors in finance panel data sets: Comparing approaches. Review of Financial Studies. 22 (1), 435-480.

Pham, P. K., Suchard, J.-A., Zein, J., 2011. Corporate governance and alternative performance measures: Evidence from Australian firms. Australian Journal of Management. 36 (3), 371-386.

Platt, H., Platt, M., 2012. Corporate board attributes and bankruptcy. Journal of Business Research. 65 (8), 1139-1143.

Prommin, P., Jumreornvong, S., Jiraporn, P., 2014. The effect of corporate governance on stock liquidity: The case of Thailand. International Review of Economics \& Finance. 32, 132-142.

Roodman, D., 2009. A note on the theme of too many instruments. Oxford Bulletin of Economics and statistics. 71 (1), 135-158.

Rutherford, M. A., Buchholtz, A. K., 2007. Investigating the relationship between board characteristics and board information. Corporate Governance: An International Review. 15 (4), 576-584.

Switzer, L. N., Wang, J., 2013. Default risk estimation, bank credit risk, and corporate governance. Financial Markets, Institutions \& Instruments. 22 (2), 91-112.

Tinic, S. M., 1972. The economics of liquidity services. The Quarterly Journal of Economics. 86 (1), 79-93.

Upadhyay, A. D., Bhargava, R., Faircloth, S. D., 2014. Board structure and role of monitoring committees. Journal of Business Research. 67 (7), 1486-1492.

Welker, M., 1995. Disclosure policy, information asymmetry, and liquidity in equity markets. Contemporary Accounting Research. 11 (2), 801-827.

Windmeijer, F., 2005. A finite sample correction for the variance of linear efficient twostep gmm estimators. Journal of econometrics. 126 (1), 25-51.

Yang, T., Zhao, S., 2014. CEO duality and firm performance: Evidence from an exogenous shock to the competitive environment. Journal of Banking \& Finance. 49, 534-552. 
Table 1: Definition of variables

\begin{tabular}{|c|c|c|}
\hline Notations & Variable names & Measures \\
\hline \multicolumn{3}{|c|}{ Panel A: Dependent variables (Stock liquidity) } \\
\hline \multicolumn{3}{|c|}{ Trading cost measures (tightness) } \\
\hline TWQS & $\begin{array}{l}\text { Time-weighted } \\
\text { quoted spread }\end{array}$ & $\begin{array}{l}\text { Daily ratio of time-weighted bid-ask spread divided by time- } \\
\text { weighted mid-point spread averaged over a number of trading } \\
\text { days in the financial year }\end{array}$ \\
\hline ZERO & $\begin{array}{l}\text { Zero return } \\
\text { measure }\end{array}$ & $\begin{array}{l}\text { Proportion of zero daily returns over a number of trading days } \\
\text { in the financial year }\end{array}$ \\
\hline \multicolumn{3}{|c|}{ Price impact measures (depth) } \\
\hline ILLIQ & $\begin{array}{l}\text { Amihud illiquidity } \\
\text { estimate }\end{array}$ & $\begin{array}{l}\text { Daily ratio of absolute stock return to trading volume in } \\
\text { Australian dollars averaged over a number of trading days in } \\
\text { the financial year }\end{array}$ \\
\hline AMIVEST & Liquidity ratio & $\begin{array}{l}\text { Sum of daily trading volume to the sum of absolute stock return } \\
\text { in a financial year }\end{array}$ \\
\hline \multicolumn{3}{|c|}{ Trading frequency measures (immediacy) } \\
\hline STO & Stock turnover & $\begin{array}{l}\text { Sum of daily shares traded to the number of shares outstanding } \\
\text { in the financial year }\end{array}$ \\
\hline LM & $\begin{array}{l}\text { Turnover-adjusted } \\
\text { zero daily volumes }\end{array}$ & Turnover-adjusted zero daily volumes \\
\hline TRADES & Number of trades & Average of number of transactions during the year \\
\hline LEVELS & Number of levels & Average of number of levels during the year \\
\hline VOLUME & Trading volume & Total number of shares traded during the year \\
\hline \multicolumn{3}{|c|}{ Panel B: Main independent variable (Corporate governance quality) } \\
\hline CG index & $\begin{array}{l}\text { Corporate } \\
\text { governance index }\end{array}$ & $\begin{array}{l}\text { Self-constructed corporate governance index based on } 17 \\
\text { objective criteria of the Horwath report }\end{array}$ \\
\hline \multicolumn{3}{|l|}{$\begin{array}{l}\text { Governance } \\
\text { categories }\end{array}$} \\
\hline \multicolumn{3}{|l|}{ categories } \\
\hline Board & $\begin{array}{l}\text { Board quality } \\
\text { index }\end{array}$ & $\begin{array}{l}\text { Board quality is a self-constructed board quality index based on } \\
\text { respective criteria, which ranges from } 0 \text { to } 3\end{array}$ \\
\hline Audit & Audit quality index & $\begin{array}{l}\text { Audit quality is a self-constructed audit quality index based on } \\
\text { respective criteria, which ranges from } 0 \text { to } 6\end{array}$ \\
\hline Nomination & $\begin{array}{l}\text { Nomination quality } \\
\text { index }\end{array}$ & $\begin{array}{l}\text { Nomination quality is a self-constructed governance category } \\
\text { based on respective criteria, which ranges from } 0 \text { to } 4\end{array}$ \\
\hline Remuneratio & $\begin{array}{l}\text { Remuneration } \\
\text { quality index }\end{array}$ & $\begin{array}{l}\text { Remuneration quality is a self-constructed governance category } \\
\text { based on respective criteria, which ranges from } 0 \text { to } 4\end{array}$ \\
\hline \multicolumn{3}{|c|}{ Panel C: Control variables (Firm characteristics) } \\
\hline $\mathrm{MC}$ & Firm size & $\begin{array}{l}\text { Number of shares outstanding times share price at the end of } \\
\text { fiscal year }\end{array}$ \\
\hline TLTA & Leverage & Book value of total liabilities over book value of total assets \\
\hline VOLATILITY & Return volatility & Standard deviation of daily stock returns \\
\hline TANGIBILITY & Asset tangibility & Net property, plant and equipment to total assets \\
\hline PRICE & Stock price & Reciprocal or inverse of stock price \\
\hline AGE & Firm age & $\begin{array}{l}\text { Number of year firm is listed on the ASX at the end of each } \\
\text { fiscal year }\end{array}$ \\
\hline MTB & $\begin{array}{l}\text { Growth } \\
\text { opportunities }\end{array}$ & Market value to book value ratio \\
\hline \multicolumn{3}{|c|}{ Panel D: Fixed effects } \\
\hline YR & Year effect & $\begin{array}{l}\text { Thirteen individual dummy variables which equals either ' } 1 \text { ' or } \\
\text { ' } 0 \text { ' for each year from } 2001 \text { to } 2013 \text { with } 2001 \text { being the } \\
\text { excluded year }\end{array}$ \\
\hline IND & Industry effect & $\begin{array}{l}\text { Nine individual dummy variables which equals either ' } 1 \text { ' or ' } 0 \text { ' } \\
\text { for each industry from Consumer Staples, Health Care, } \\
\text { Information Technology, Industrials, Materials, Consumer } \\
\text { Discretionary, Energy, Utility, Telecommunication Services } \\
\text { with Telecommunication Services being excluded. The industry } \\
\text { classification is based on Standard \& Poor's two-digit Global } \\
\text { Industry Classification Scheme (GICS) }\end{array}$ \\
\hline
\end{tabular}




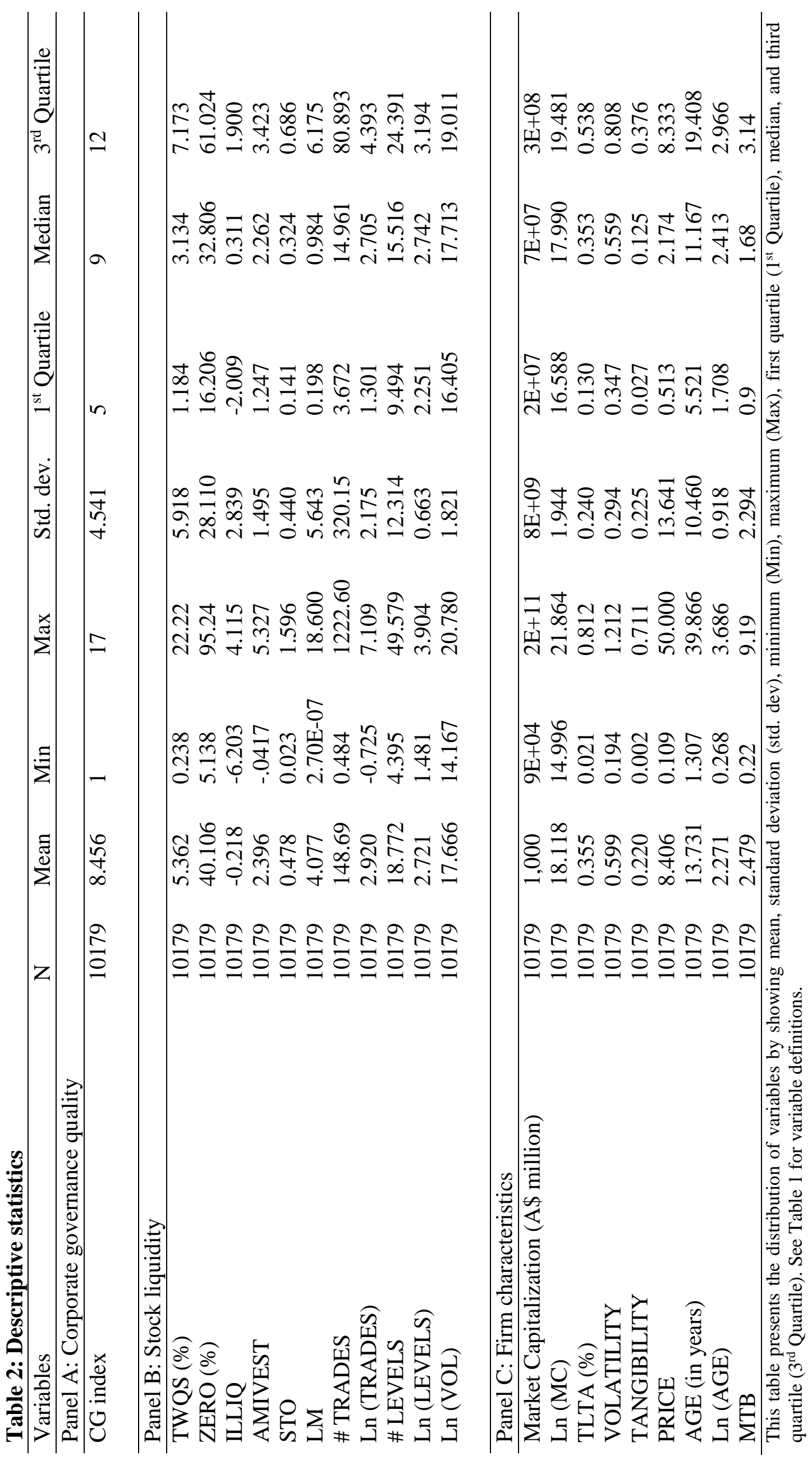

ले 


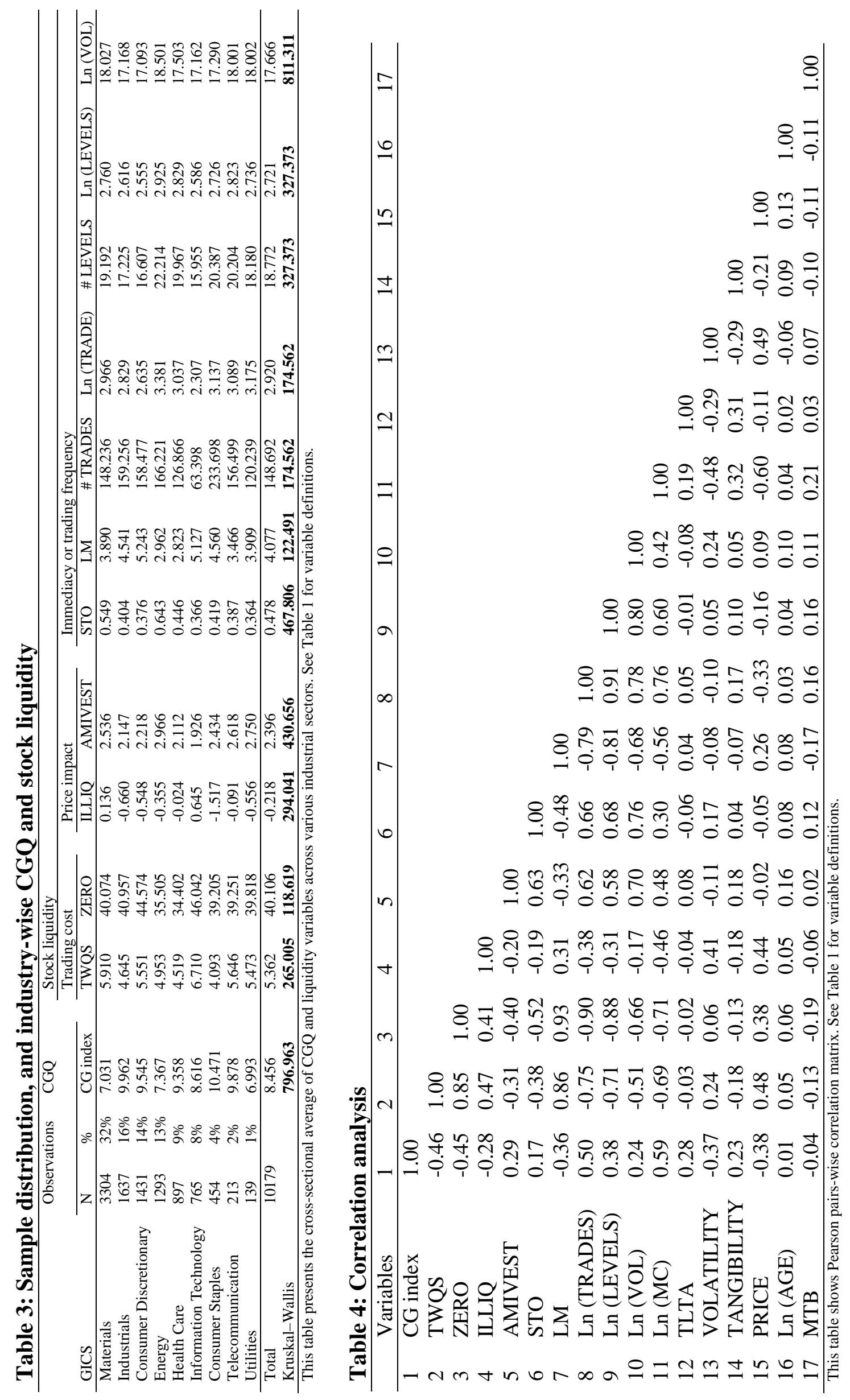


Table 5: CGQ and stock liquidity: Pooled ordinary least squares (H1a, 1b, 1c)

\begin{tabular}{|c|c|c|c|c|c|c|}
\hline \multirow[b]{3}{*}{$\begin{array}{l}\text { Dep. } \\
\text { variables }\end{array}$} & \multicolumn{2}{|c|}{ Trading cost } & \multicolumn{2}{|c|}{ Price impact } & \multicolumn{2}{|c|}{ Immediacy } \\
\hline & $\begin{array}{l}\text { Model } 1 \\
\text { (t-stats) }\end{array}$ & $\begin{array}{c}\text { Model } 2 \\
\text { (t-stats) }\end{array}$ & $\begin{array}{l}\text { Model } 3 \\
(t \text {-stats) }\end{array}$ & $\begin{array}{c}\text { Model } 4 \\
\text { (t-stats) }\end{array}$ & $\begin{array}{l}\text { Model } 5 \\
\text { (t-stats) }\end{array}$ & $\begin{array}{c}\text { Model } 6 \\
\text { (t-stats) }\end{array}$ \\
\hline & $\begin{array}{c}\text { TWQS } \\
\text { (Clustered by } \\
\text { firm) }\end{array}$ & $\begin{array}{c}\text { ZERO } \\
\text { (Clustered by } \\
\text { firm) }\end{array}$ & $\begin{array}{c}\text { ILLIQ } \\
\text { (Clustered by } \\
\text { firm) }\end{array}$ & $\begin{array}{c}\text { AMIVEST } \\
\text { (Clustered by } \\
\text { firm) }\end{array}$ & $\begin{array}{c}\text { STO } \\
\text { (Clustered by } \\
\text { firm) }\end{array}$ & $\begin{array}{c}\text { LM } \\
\text { (Clustered by } \\
\text { firm) }\end{array}$ \\
\hline Corporate go & rnance quality & & & & & \\
\hline CG index & $\begin{array}{c}-0.162 * * * \\
(-7.90)\end{array}$ & $\begin{array}{c}-0.790 * * * \\
(-8.06)\end{array}$ & $\begin{array}{c}-0.031^{* * * *} \\
(-3.44)\end{array}$ & $\begin{array}{c}0.015^{* * * *} \\
(2.62)\end{array}$ & $\begin{array}{c}0.008 * * * \\
(4.19)\end{array}$ & $\begin{array}{c}-0.177 * * * \\
(-7.99)\end{array}$ \\
\hline Firm characte & stics & & & & & \\
\hline Ln (MC) & $\begin{array}{c}-2.052 * * * \\
(-21.09)\end{array}$ & $\begin{array}{c}-12.072 * * * \\
(-29.07)\end{array}$ & $\begin{array}{c}-1.082 * * * \\
(-23.74)\end{array}$ & $\begin{array}{c}1.012 * * * \\
(39.75)\end{array}$ & $\begin{array}{c}0.115^{* * * *} \\
(13.25)\end{array}$ & $\begin{array}{c}-2.456 * * * \\
(-25.08)\end{array}$ \\
\hline TLTA & $\begin{array}{c}2.554^{* * * *} \\
\quad(6.25)\end{array}$ & $\begin{array}{c}4.666 * * * \\
(2.74)\end{array}$ & $\begin{array}{c}-0.291 * * \\
(-2.00)\end{array}$ & $\begin{array}{l}0.035 \\
(0.39)\end{array}$ & $\begin{array}{l}0.024 \\
(0.73)\end{array}$ & $\begin{array}{c}1.559 * * * \\
(3.76)\end{array}$ \\
\hline VOLATILIT & & & & & & \\
\hline Y & $\begin{array}{c}-4.094 * * * \\
(-9.75)\end{array}$ & $\begin{array}{c}-36.332 * * * \\
(-24.90)\end{array}$ & $\begin{array}{c}1.855 * * * \\
(13.33)\end{array}$ & $\begin{array}{l}-0.124 \\
(-1.41)\end{array}$ & $\begin{array}{c}0.622 * * * \\
(20.89)\end{array}$ & $\begin{array}{c}-8.798 * * * \\
(-23.50)\end{array}$ \\
\hline TANGIBILI & & & & & & \\
\hline TY & $\begin{array}{l}0.104 \\
(0.27)\end{array}$ & $\begin{array}{c}6.051 * * * \\
(3.28)\end{array}$ & $\begin{array}{l}0.086 \\
(0.48)\end{array}$ & $\begin{array}{l}-0.143 \\
(-1.48)\end{array}$ & $\begin{array}{l}-0.045 \\
(-1.27)\end{array}$ & $\begin{array}{c}1.199 * * * \\
(2.78)\end{array}$ \\
\hline PRICE & $\begin{array}{c}-0.278 * * * \\
(-2.87)\end{array}$ & $\begin{array}{l}-0.374 \\
(-0.84)\end{array}$ & $\begin{array}{l}0.073^{*} \\
(1.73)\end{array}$ & $\begin{array}{c}-0.807 * * * \\
(-29.98)\end{array}$ & $\begin{array}{l}-0.014 \\
(-1.59)\end{array}$ & $\begin{array}{c}0.367 * * * \\
(3.65)\end{array}$ \\
\hline Ln (AGE) & $\begin{array}{c}0.363 * * * \\
(4.19)\end{array}$ & $\begin{array}{c}1.899 * * * \\
(4.57)\end{array}$ & $\begin{array}{l}-0.059 \\
(-1.55)\end{array}$ & $\begin{array}{c}0.064 * * * \\
(2.65)\end{array}$ & $\begin{array}{c}0.030 * * * \\
(3.66)\end{array}$ & $\begin{array}{c}0.435 * * * \\
(4.75)\end{array}$ \\
\hline МТВ & $\begin{array}{c}0.138 * * * \\
(4.37)\end{array}$ & $\begin{array}{c}0.357 * * \\
(2.57)\end{array}$ & $\begin{array}{c}0.035 * * * \\
(2.62)\end{array}$ & $\begin{array}{l}-0.000 \\
(-0.02)\end{array}$ & $\begin{array}{l}-0.002 \\
(-0.65)\end{array}$ & $\begin{array}{c}0.086^{* * * *} \\
(2.78)\end{array}$ \\
\hline $\begin{array}{l}\text { Industry } \\
\text { effect }\end{array}$ & Yes & Yes & Yes & Yes & Yes & Yes \\
\hline Year effect & Yes & Yes & Yes & Yes & Yes & Yes \\
\hline Intercept & $\begin{array}{c}41.570 * * * \\
(24.48)\end{array}$ & $\begin{array}{c}269.327 * * * \\
(36.91)\end{array}$ & $\begin{array}{c}19.443 * * * \\
(22.14)\end{array}$ & $\begin{array}{c}-17.357 * * * \\
(-37.92)\end{array}$ & $\begin{array}{c}-2.324 * * * \\
(-15.17)\end{array}$ & $\begin{array}{c}50.222 * * * \\
(29.49)\end{array}$ \\
\hline Model fits: & & & & & & \\
\hline Adj. $R^{2}$ & 0.547 & 0.640 & 0.697 & 0.610 & 0.283 & 0.535 \\
\hline$F$-statistics & $110.96 * * *$ & $247.91 * * *$ & $193.49 * * *$ & $167.93 * * *$ & $51.15^{* * *}$ & $106.71 * * *$ \\
\hline $\mathrm{N}$ & 10179 & 10179 & 10179 & 10179 & 10179 & 10179 \\
\hline No. of firms & 1207 & 1207 & 1207 & 1207 & 1207 & 1207 \\
\hline
\end{tabular}

This table presents the results of pooled ordinary least square estimates of Eq. (9).

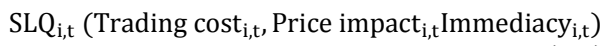

$$
\begin{aligned}
& =\alpha_{0}+\beta_{1} \mathrm{CGQ}_{\mathrm{i}, \mathrm{t}}+\beta_{2} \operatorname{Ln}(\mathrm{MC})_{\mathrm{i}, \mathrm{t}}+\beta_{3} \text { TLTA }_{\mathrm{i}, \mathrm{t}}+\beta_{4} \text { VOLATILITY }_{\mathrm{i}, \mathrm{t}}+\beta_{5} \text { TANGIBILITY }_{\mathrm{i}, \mathrm{t}}+\beta_{6} \ln \left(\text { PRICE }_{\mathrm{i}, \mathrm{t}}+\beta_{7} \operatorname{Ln}(\mathrm{AGE})_{\mathrm{i}, \mathrm{t}}\right. \\
& +\beta_{8} \mathrm{MTB}_{\mathrm{i}, \mathrm{t}}+\delta \mathrm{YR}_{\mathrm{t}}+\emptyset \operatorname{IND}_{\mathrm{i}}+\varepsilon_{\mathrm{i}, \mathrm{t}}
\end{aligned}
$$

Subscripts $i$ denotes individual firms, $t$ time period, $\ln$ natural logarithm. The dependent variable, $S L Q$, is either time-weighted quoted spread (TWQS in Model 1) or proportion of zero return days (ZERO in Model 2) or Amihud illiquidity measure (ILLIQ in Model 3) or liquidity ratio (AMIVEST in Model 4) or trading turnover (STO in Model 5) or turnover-adjusted zero daily volumes (LM in Model 6). CG index is self-constructed index based on 17 objective criteria of the Horwath report; Ln (MC) is the natural log of market capitalization; TLTA is measured by the ratio of total liabilities to total assets; VOLATILITY is the standard deviation of daily stock returns; TANGIBILITY is net property, plant and equipment to total assets; PRICE is the reciprocal or natural log of stock price; Ln (AGE) is the natural log of number of years since the firm had been listed on the ASX by the end of its financial year. YR is a year dummy. IND is an industry dummy. $\alpha, \beta, \delta$, and $\emptyset$ are the parameters to be estimated. $\varepsilon$ is the idiosyncratic error term. Figures in parenthesis are the t-statistics. Superscripts $* * *, * *, *$ indicate statistical significance at $1 \%, 5 \%$, and $10 \%$ respectively. 


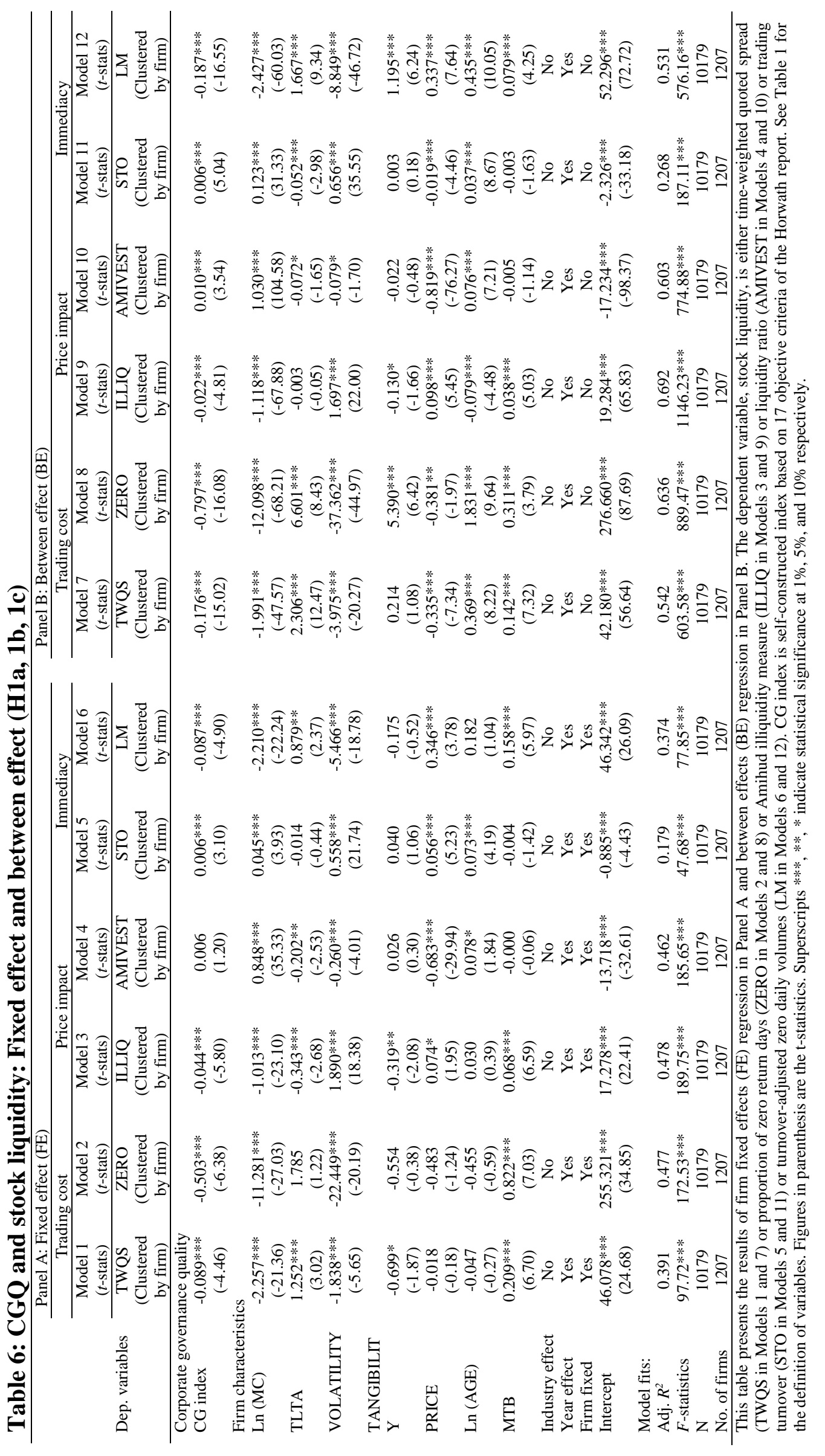




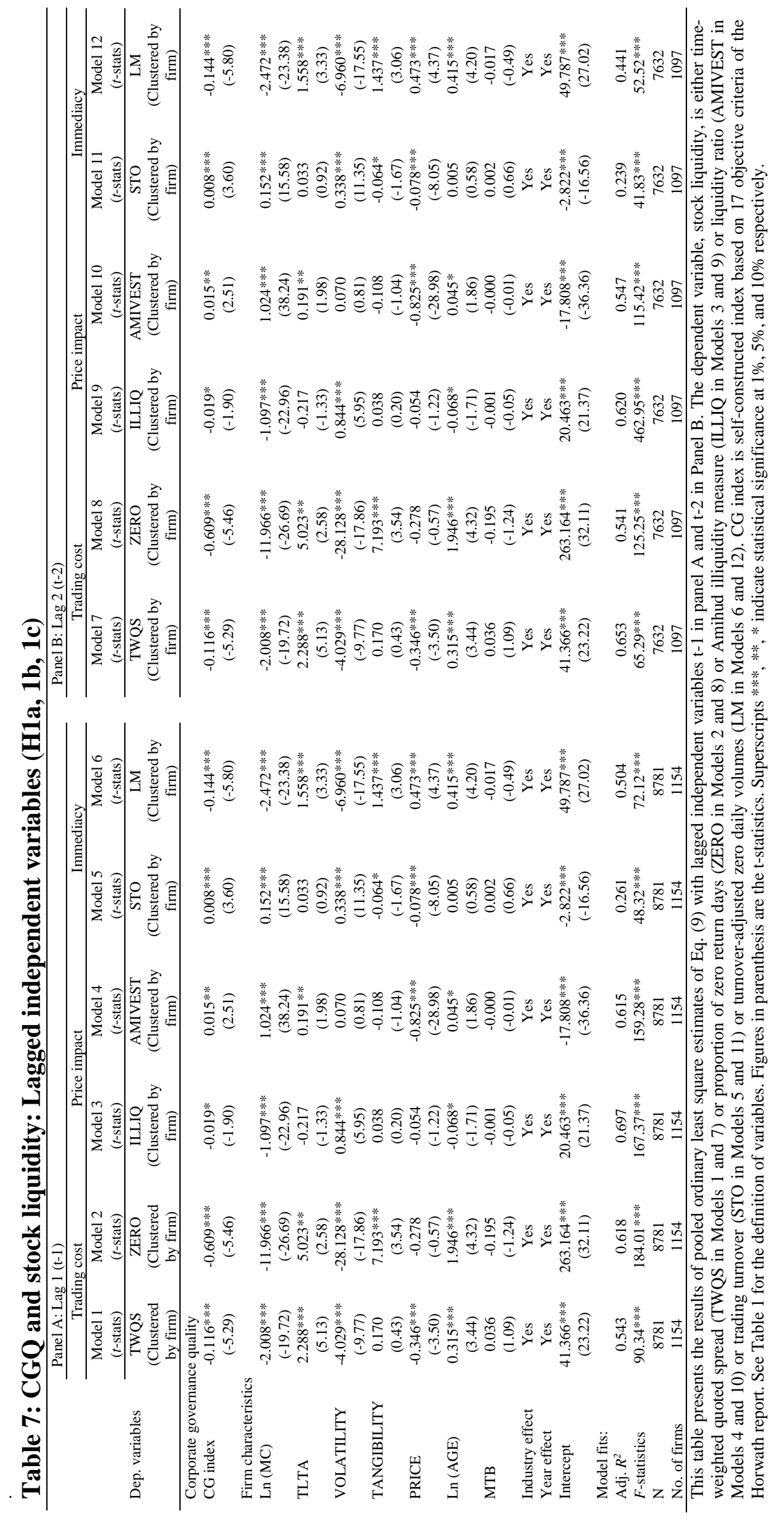


Table 8: CGQ and stock liquidity: Instrumental variable approach (H1a, 1b, 1c)

\begin{tabular}{|c|c|c|c|c|c|c|c|}
\hline \multirow{4}{*}{ Dep. variables } & \multirow{3}{*}{$\begin{array}{l}\text { First stage } \\
\text { Model } 1 \\
(t \text {-stats) } \\
\end{array}$} & \multicolumn{6}{|c|}{ Second stage } \\
\hline & & \multicolumn{2}{|c|}{ Trading cost } & \multicolumn{2}{|c|}{ Price impact } & \multicolumn{2}{|l|}{ Immediacy } \\
\hline & & $\begin{array}{l}\text { Model } 2 \\
\text { (t-stats) }\end{array}$ & $\begin{array}{l}\text { Model } 3 \\
\text { (t-stats) }\end{array}$ & $\begin{array}{l}\text { Model } 4 \\
\text { (t-stats) }\end{array}$ & $\begin{array}{l}\text { Model } 5 \\
\text { (t-stats) }\end{array}$ & $\begin{array}{l}\text { Model } 6 \\
(t \text {-stats) }\end{array}$ & $\begin{array}{l}\text { Model } 7 \\
\text { (t-stats) }\end{array}$ \\
\hline & CG index & TWQS & ZERO & ILLIQ & AMIVEST & STO & LM \\
\hline \multicolumn{8}{|c|}{ Corporate governance quality } \\
\hline CG reforms & $\begin{array}{l}1.844^{* * *} \\
22.39\end{array}$ & & & & & & \\
\hline Industry CGQ & $\begin{array}{l}0.618^{* * *} \\
(20.38)\end{array}$ & & & & & & \\
\hline Fitted CGQ & & $\begin{array}{l}-0.221 * * * \\
(-5.41)\end{array}$ & $\begin{array}{l}-0.493 * * * \\
(-2.87)\end{array}$ & $\begin{array}{l}-0.049 * * * \\
(3.11)\end{array}$ & $\begin{array}{l}0.030 * * * \\
(2.82)\end{array}$ & $\begin{array}{l}0.002 \\
(0.41)\end{array}$ & $\begin{array}{l}-0.123 * * * \\
(-3.08)\end{array}$ \\
\hline \multicolumn{8}{|l|}{ Firm characteristics } \\
\hline \multicolumn{8}{|l|}{ Ln (MC) } \\
\hline TLTA & $\begin{array}{l}2.180 * * * \\
(13.19)\end{array}$ & $\begin{array}{l}2.434 * * * \\
(10.56)\end{array}$ & $\begin{array}{l}5.880^{* * * *} \\
(6.08)\end{array}$ & $\begin{array}{l}-0.174 * \\
(-1.95)\end{array}$ & $\begin{array}{l}-0.446 * * * \\
(-7.31)\end{array}$ & $\begin{array}{l}-0.072 * * * \\
(-3.36)\end{array}$ & $\begin{array}{l}1.616^{* * * *} \\
(7.21)\end{array}$ \\
\hline VOLATILITY & $\begin{array}{l}0.274^{*} \\
(1.85)\end{array}$ & $\begin{array}{l}-2.872 * * * \\
(-16.25)\end{array}$ & $\begin{array}{l}-33.965 * * * \\
(-45.83)\end{array}$ & $\begin{array}{l}1.785^{* * * *} \\
(26.19)\end{array}$ & $\begin{array}{l}0.727 * * * \\
(15.58)\end{array}$ & $\begin{array}{l}0.591 * * * \\
(36.01)\end{array}$ & $\begin{array}{l}-8.429 * * * \\
(-49.06)\end{array}$ \\
\hline TANGIBILITY & $\begin{array}{l}0.251 \\
(1.48)\end{array}$ & $\begin{array}{l}0.173 \\
(0.84)\end{array}$ & $\begin{array}{l}5.412^{* * * *} \\
(6.27)\end{array}$ & $\begin{array}{l}-0.095 \\
(-1.20)\end{array}$ & $\begin{array}{l}0.023 \\
(0.43)\end{array}$ & $\begin{array}{l}-0.009 \\
(-0.49)\end{array}$ & $\begin{array}{l}1.106 * * * \\
(5.53)\end{array}$ \\
\hline PRICE & $\begin{array}{l}-0.009 * * * \\
(-2.67)\end{array}$ & $\begin{array}{l}0.058 * * * \\
(14.39)\end{array}$ & $\begin{array}{l}0.041 * * \\
(2.44)\end{array}$ & $\begin{array}{l}-0.014 * * * \\
(-8.69)\end{array}$ & $\begin{array}{l}0.054^{* * *} \\
(50.28)\end{array}$ & $\begin{array}{l}0.002 * * * \\
(5.86)\end{array}$ & $\begin{array}{l}0.000 \\
(0.10)\end{array}$ \\
\hline Ln (AGE) & $\begin{array}{l}-0.188 * * * \\
(-4.96)\end{array}$ & $\begin{array}{l}0.348^{* * * *} \\
(7.48)\end{array}$ & $\begin{array}{l}2.172^{* * *} \\
(11.13)\end{array}$ & $\begin{array}{l}-0.032 * \\
(-1.80)\end{array}$ & $\begin{array}{l}0.050^{* * * *} \\
(4.06)\end{array}$ & $\begin{array}{l}0.033^{* * *} \\
(7.67)\end{array}$ & $\begin{array}{l}0.517 * * * \\
(11.43)\end{array}$ \\
\hline MTB & $\begin{array}{l}-0.331 * * * \\
(-21.39)\end{array}$ & $\begin{array}{l}0.041^{*} \\
(1.75)\end{array}$ & $\begin{array}{l}0.185^{*} \\
(1.88)\end{array}$ & $\begin{array}{l}0.060^{* * * *} \\
(6.65)\end{array}$ & $\begin{array}{l}-0.037 * * * \\
(-5.98)\end{array}$ & $\begin{array}{l}-0.000 \\
(-0.20)\end{array}$ & $\begin{array}{l}0.058 * * \\
(2.56)\end{array}$ \\
\hline Industry effect (IND) & No & No & No & No & No & No & No \\
\hline Year effect & No & No & No & No & No & No & No \\
\hline Intercept & $(-37.29)$ & $\begin{array}{l}39.906 * * * \\
(48.01)\end{array}$ & $\begin{array}{l}278.277 * * * \\
(79.82)\end{array}$ & $\begin{array}{l}19.959 * * * \\
(62.24)\end{array}$ & $\begin{array}{l}-10.304 * * * \\
(-46.91)\end{array}$ & $\begin{array}{l}-2.140 * * * \\
(-27.70)\end{array}$ & $\begin{array}{l}47.348^{* * * *} \\
(58.59)\end{array}$ \\
\hline \multicolumn{7}{|l|}{ Model fits: } & 0.619 \\
\hline$F$-statistics & $929.98 * * *$ & N/A & N/A & $\begin{array}{l}0.004 \\
\text { N/A }\end{array}$ & $\begin{array}{l}0.400 \\
\mathrm{~N} / \mathrm{A}\end{array}$ & $\begin{array}{l}0.23 / \\
\text { N/A }\end{array}$ & $\begin{array}{l}0.019 \\
\text { N/A }\end{array}$ \\
\hline $\mathrm{N}$ & 10179 & 10179 & 10179 & 10179 & 10179 & 10179 & 10179 \\
\hline No. of firms & 1207 & 1207 & 1207 & 1207 & 1207 & 1207 & 1207 \\
\hline $\begin{array}{l}\text { This table presents the } \\
\text { index based on } 17 \text { ob } \\
\text { otherwise } 0 \text {; Industry- } \\
\text { The dependent variab } \\
\text { return days (ZERO in } \\
\text { (STO in Model 6) or t } \\
\text { t-statistics Suprscris }\end{array}$ & $\begin{array}{l}\text { tage least sq } \\
\mathrm{f} \text { the Horwa } \\
\text { measured as } \\
\text { e is stock li }\end{array}$ & $\begin{array}{l}\text { (2SLS). The } \\
\text { ort; CG refo } \\
\text { stry CGQ mi } \\
\text { y which is e }\end{array}$ & t time-weigh & quoted spr & $\begin{array}{l}\text { CGQ which } \\
\text { the value } 1 \\
\text { otal observati } \\
\text { (TWQS in } N \\
\text { AMIVEST in } \\
\text { n of variables }\end{array}$ & $\begin{array}{l}\text { self-constru } \\
\text { year is fror } \\
\text { in an ind } \\
\text { lel 2) or pr } \\
\text { lodel 5) or }\end{array}$ & $\begin{array}{l}\text { d governance } \\
004 \text { to 2013, } \\
\text { minus one). } \\
\text { rtion of zero } \\
\text { ling turnover } \\
\text { thesis are the }\end{array}$ \\
\hline
\end{tabular}


Table 9: CGQ and stock liquidity: Dynamic panel data estimation (H1a, 1b, 1c)

\begin{tabular}{|c|c|c|c|c|c|c|}
\hline \multirow{3}{*}{ Dep. variables } & \multicolumn{2}{|l|}{ Trading cost } & \multicolumn{2}{|c|}{ Price impact } & \multicolumn{2}{|l|}{ Immediacy } \\
\hline & $\begin{array}{l}\text { Model } 1 \\
\text { (t-stats) }\end{array}$ & $\begin{array}{l}\text { Model } 2 \\
(t \text {-stats })\end{array}$ & $\begin{array}{l}\text { Model } 3 \\
(t \text {-stats) }\end{array}$ & $\begin{array}{l}\text { Model } 4 \\
\text { (t-stats) }\end{array}$ & $\begin{array}{l}\text { Model } 5 \\
\text { (t-stats) }\end{array}$ & $\begin{array}{l}\text { Model } 6 \\
\text { (t-stats) }\end{array}$ \\
\hline & TWQS & ZERO & ILLIQ & AMIVEST & STO & LM \\
\hline L.SLQ & $\begin{array}{l}0.370^{* * *} \\
(3.82)\end{array}$ & $\begin{array}{l}0.769 * * * \\
(5.64)\end{array}$ & $\begin{array}{l}1.303^{* * *} \\
(2.88)\end{array}$ & $\begin{array}{l}0.073 \\
(0.59)\end{array}$ & $\begin{array}{l}0.199 * * \\
(2.12)\end{array}$ & $\begin{array}{l}0.804 * * * \\
(4.08)\end{array}$ \\
\hline \multicolumn{7}{|c|}{ Corporate governance quality } \\
\hline CG index & $\begin{array}{l}-0.069 * * * \\
(-2.72)\end{array}$ & $\begin{array}{l}-0.365^{* * *} \\
(-3.37)\end{array}$ & $\begin{array}{l}-0.064 * * * \\
(-3.64)\end{array}$ & $\begin{array}{l}0.008 * \\
(1.69)\end{array}$ & $\begin{array}{l}0.007 * * * \\
(4.00)\end{array}$ & $\begin{array}{l}-0.050 * * \\
(-1.98)\end{array}$ \\
\hline \multicolumn{7}{|l|}{ Firm characteristics } \\
\hline $\operatorname{Ln}(\mathrm{MC})$ & $\begin{array}{l}-0.818^{* * *} \\
(-4.30)\end{array}$ & $\begin{array}{l}-1.943 \\
(-1.08)\end{array}$ & $\begin{array}{l}0.348 \\
(0.63)\end{array}$ & $\begin{array}{l}0.976^{* * *} \\
(8.62)\end{array}$ & $\begin{array}{l}0.072^{* * *} \\
(4.68)\end{array}$ & $\begin{array}{l}-0.286 \\
(-0.60)\end{array}$ \\
\hline TLTA & $\begin{array}{l}1.611^{* * *} \\
(6.25)\end{array}$ & $\begin{array}{l}4.665^{* * *} \\
(6.14)\end{array}$ & $\begin{array}{l}1.313^{* *} \\
(2.57)\end{array}$ & $\begin{array}{l}-0.049 \\
(-0.76)\end{array}$ & $\begin{array}{l}-0.033 \\
(-1.21)\end{array}$ & $\begin{array}{l}0.753^{* * *} \\
(3.52)\end{array}$ \\
\hline VOLATILITY & $\begin{array}{l}-3.238 * * * \\
(-11.67)\end{array}$ & $\begin{array}{l}-20.652 * * * \\
(-14.61)\end{array}$ & $\begin{array}{l}0.922^{* *} \\
(2.19)\end{array}$ & $\begin{array}{l}-0.169 * * \\
(-2.40)\end{array}$ & $\begin{array}{l}0.583^{* * *} \\
(16.78)\end{array}$ & $\begin{array}{l}-4.735 * * * \\
(-9.09)\end{array}$ \\
\hline TANGIBILITY & $\begin{array}{l}-0.029 \\
(-0.12)\end{array}$ & $\begin{array}{l}0.784 \\
(0.87)\end{array}$ & $\begin{array}{l}0.279 \\
(1.40)\end{array}$ & $\begin{array}{l}0.004 \\
(0.05)\end{array}$ & $\begin{array}{l}0.033 \\
(1.18)\end{array}$ & $\begin{array}{l}0.108 \\
(0.47)\end{array}$ \\
\hline PRICE & $\begin{array}{l}-0.901 * * * \\
(-7.62)\end{array}$ & $\begin{array}{l}-3.121^{* * *} \\
(-4.13)\end{array}$ & $\begin{array}{l}-0.054 \\
(-0.38)\end{array}$ & $\begin{array}{l}-0.785^{* * *} \\
(-8.58)\end{array}$ & $\begin{array}{l}0.025^{*} \\
(1.88)\end{array}$ & $\begin{array}{l}-0.611 \text { *** } \\
(-2.67)\end{array}$ \\
\hline Ln (AGE) & $\begin{array}{l}0.176^{* *} \\
(2.30)\end{array}$ & $\begin{array}{l}-0.328 \\
(-0.75)\end{array}$ & $\begin{array}{l}-0.032 \\
(-0.90)\end{array}$ & $\begin{array}{l}0.100^{* * *} \\
(4.17)\end{array}$ & $\begin{array}{l}0.023 * * * \\
(2.67)\end{array}$ & $\begin{array}{l}-0.079 \\
(-0.59)\end{array}$ \\
\hline MTB & $\begin{array}{l}0.105^{* * *} \\
(3.44)\end{array}$ & $\begin{array}{l}-0.297 * * \\
(-2.04)\end{array}$ & $\begin{array}{l}-0.145^{* *} \\
(-2.16)\end{array}$ & $\begin{array}{l}-0.003 \\
(-0.46)\end{array}$ & $\begin{array}{l}-0.001 \\
(-0.60)\end{array}$ & $\begin{array}{l}0.002 \\
(0.07)\end{array}$ \\
\hline Industry effect (IND) & No & No & No & No & No & No \\
\hline Year effect & Yes & Yes & Yes & Yes & Yes & Yes \\
\hline Intercept & $\begin{array}{l}19.372^{* * *} \\
(4.98)\end{array}$ & $\begin{array}{l}59.018 \\
(1.54)\end{array}$ & $\begin{array}{l}-6.181 \\
(-0.63)\end{array}$ & $\begin{array}{l}-16.277 * * * \\
(-8.66)\end{array}$ & $\begin{array}{l}-1.349 * * * \\
(-5.08)\end{array}$ & $\begin{array}{l}9.146 \\
(0.97)\end{array}$ \\
\hline Model fits: & & & & & & \\
\hline Adj. $R^{2}$ & N/A & N/A & N/A & N/A & N/A & N/A \\
\hline$F$-statistics & $202.58 * * *$ & $938.8 * * *$ & $441.7^{* * *}$ & $226.8^{* * *}$ & $72.71^{* * *}$ & $528.4^{* * *}$ \\
\hline Arellano-Bond AR(1) & $\begin{array}{l}-5.03 * * * \\
{[0.000]}\end{array}$ & $\begin{array}{l}-5.70 * * * \\
{[0.000]}\end{array}$ & $\begin{array}{l}-3.09 * * * \\
{[0.002]}\end{array}$ & $\begin{array}{l}-3.29 * * * \\
{[0.000]}\end{array}$ & $\begin{array}{l}-4.87 * * * \\
{[0.000]}\end{array}$ & $\begin{array}{l}-4.19 * * * \\
{[0.000]}\end{array}$ \\
\hline Arellano-Bond AR(2) & $\begin{array}{l}-0.77 * * * \\
{[0.441]}\end{array}$ & $\begin{array}{l}-1.37 \\
{[0.170]}\end{array}$ & $\begin{array}{l}1.26 \\
{[0.207]}\end{array}$ & $\begin{array}{l}-1.58 \\
{[0.113]}\end{array}$ & $\begin{array}{l}-1.33 \\
{[0.183]}\end{array}$ & $\begin{array}{l}0.17 \\
{[0.865]}\end{array}$ \\
\hline Hansen J-statistics & $\begin{array}{l}3.07 \\
{[0.216]}\end{array}$ & $\begin{array}{l}0.91 \\
{[0.340]}\end{array}$ & $\begin{array}{l}0.06 \\
{[0.810]}\end{array}$ & $\begin{array}{l}20.5 \\
{[0.058]}\end{array}$ & $\begin{array}{l}107.16 \\
{[0.081]}\end{array}$ & $\begin{array}{l}1.34 \\
{[0.247]}\end{array}$ \\
\hline $\mathrm{N}$ & 8781 & 8781 & 8781 & 8781 & 8781 & 8781 \\
\hline No of instruments & 22 & 22 & 22 & 22 & 22 & 22 \\
\hline No. of firms & 1155 & 1155 & 1155 & 1155 & 1155 & 1155 \\
\hline
\end{tabular}

This table presents the results of dynamic two-step system GMM. The dependent variable, stock liquidity, is either time-weighted quoted spread (TWQS in Model 1) or proportion of zero return days (ZERO in Model 2) or Amihud illiquidity measure (ILLIQ in Model 3) or liquidity ratio (AMIVEST in Model 4) or trading turnover (STO in Model 5) or turnover-adjusted zero daily volumes (LM in Model 6). CG index is self-constructed index based on 17 objective criteria of the Horwath report. See Table 1 for the definition of variables. See Table 1 for the definition of variables. We use robust standard errors, incorporating the Windmeijer (2005) small-sample correction. Instruments are collapsed to reduce IV proliferation and preserve sample depth. Finally, Arellano-Bond AR (1) and AR (2) are the test statistics for first-order and second-order serial correlation, respectively. Hansen J-statistics is the test of over-identifying restrictions. Figures in parenthesis are the t-statistics. Superscripts $* * *, * *, *$ indicate statistical significance at $1 \%, 5 \%$, and $10 \%$ respectively 
Table 10: CGQ, disclosure and stock liquidity: Fixed effect regression

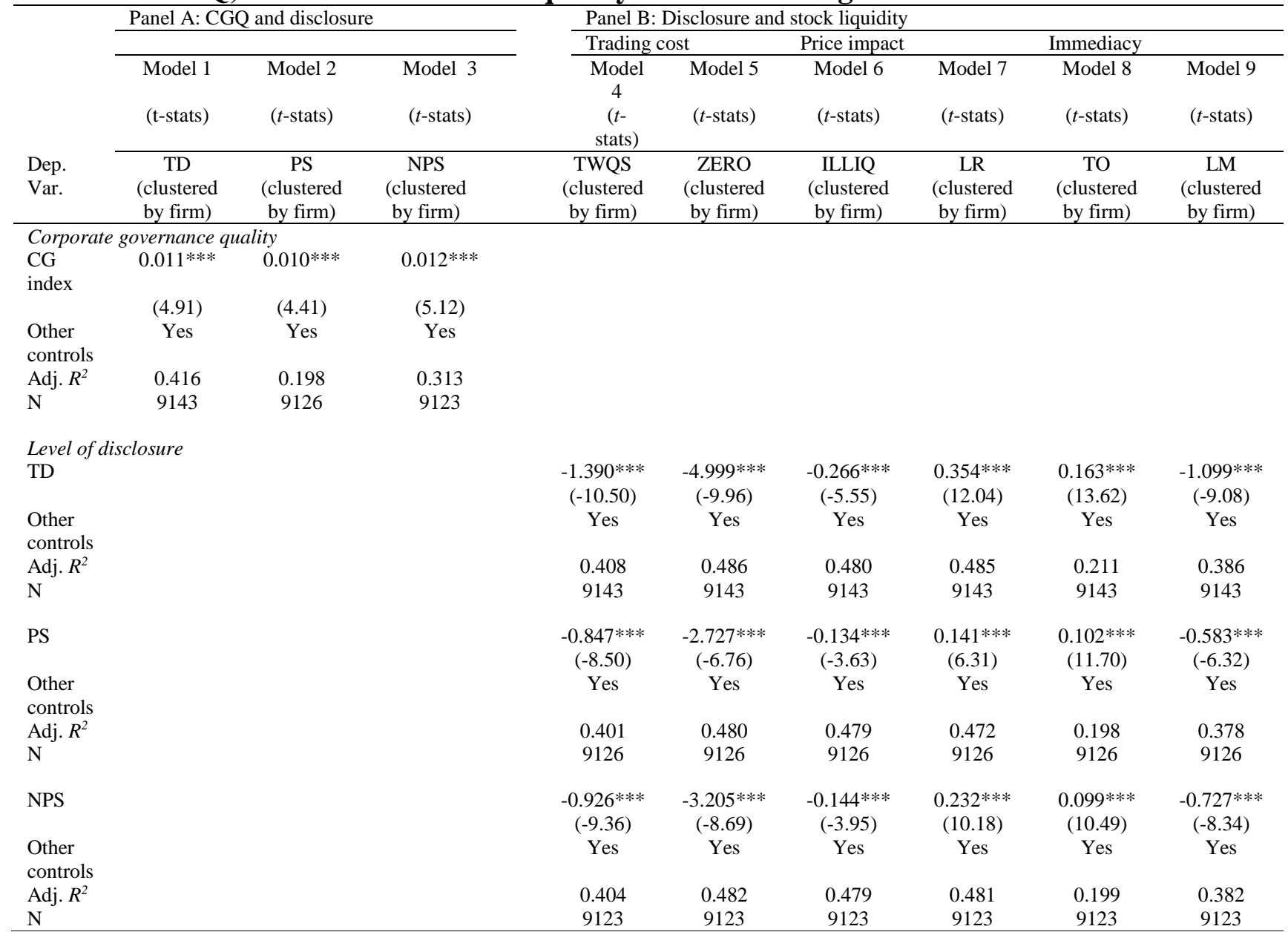

This table presents the results between CGQ and disclosure (Eq. 10) in panel A, and between disclosure and stock liquidity (Eq. 11) in panel B.

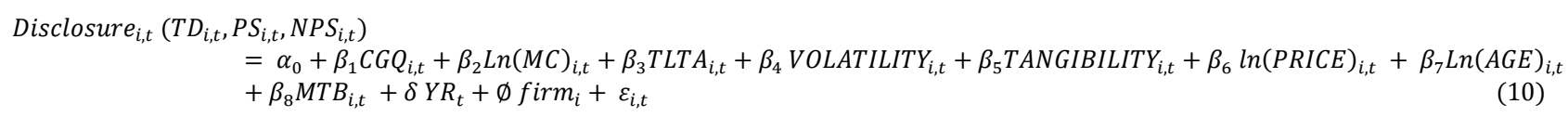

$S L Q_{i, t}\left(\right.$ Trading $_{\text {cost }} t_{i, t}$, or Price impact ${ }_{i, t}$, or Immediacy $\left._{i, t}\right)$

$=\alpha_{0}+\beta_{1}$ Disclosure $_{i, t}+\beta_{2} \operatorname{Ln}(M C)_{i, t}+\beta_{3}$ TLTA $_{i, t}+\beta_{4}$ VOLATILITY $_{i, t}+\beta_{5}$ TANGIBILITY $_{i, t}+\beta_{6} \ln (\text { PRICE })_{i, t}$

$+\beta_{7} \operatorname{Ln}(A G E)_{i, t}+\beta_{8} M T B_{i, t}+\delta Y R_{t}+\emptyset$ firm $_{i}+\varepsilon_{i, t}$

Subscripts i denotes individual firms, t time period, ln natural logarithm. The dependent variable, disclosure, in Eq. (10) is either natural logarithm of total documents (TD in Model 1) or price sensitive documents (PS in Model 2) or non-price sensitive documents (NPS in Model 3). The dependent variable, SLQ, in Eq. (11) is either time-weighted quoted spread (TWQS in Model 4) or proportion of zero return days (ZERO in Model 5) or Amihud illiquidity measure (ILLIQ in Model 6) or liquidity ratio (AMIVEST in Model 7) or trading turnover (STO in Model 8) or turnover-adjusted zero daily volumes (LM in Model 9). CG index is self-constructed index based on 17 objective criteria of the Horwath report. See Table 1 for the definition of variables. See Table 1 for the definition of variables. $\alpha, \beta, \delta$, and $\emptyset$ are the parameters to be estimated. $\varepsilon$ is the idiosyncratic error term. Figures in parenthesis are the t-statistics. Superscripts ***, **, * indicate statistical significance at 1\%, 5\%, and 10\% respectively. 


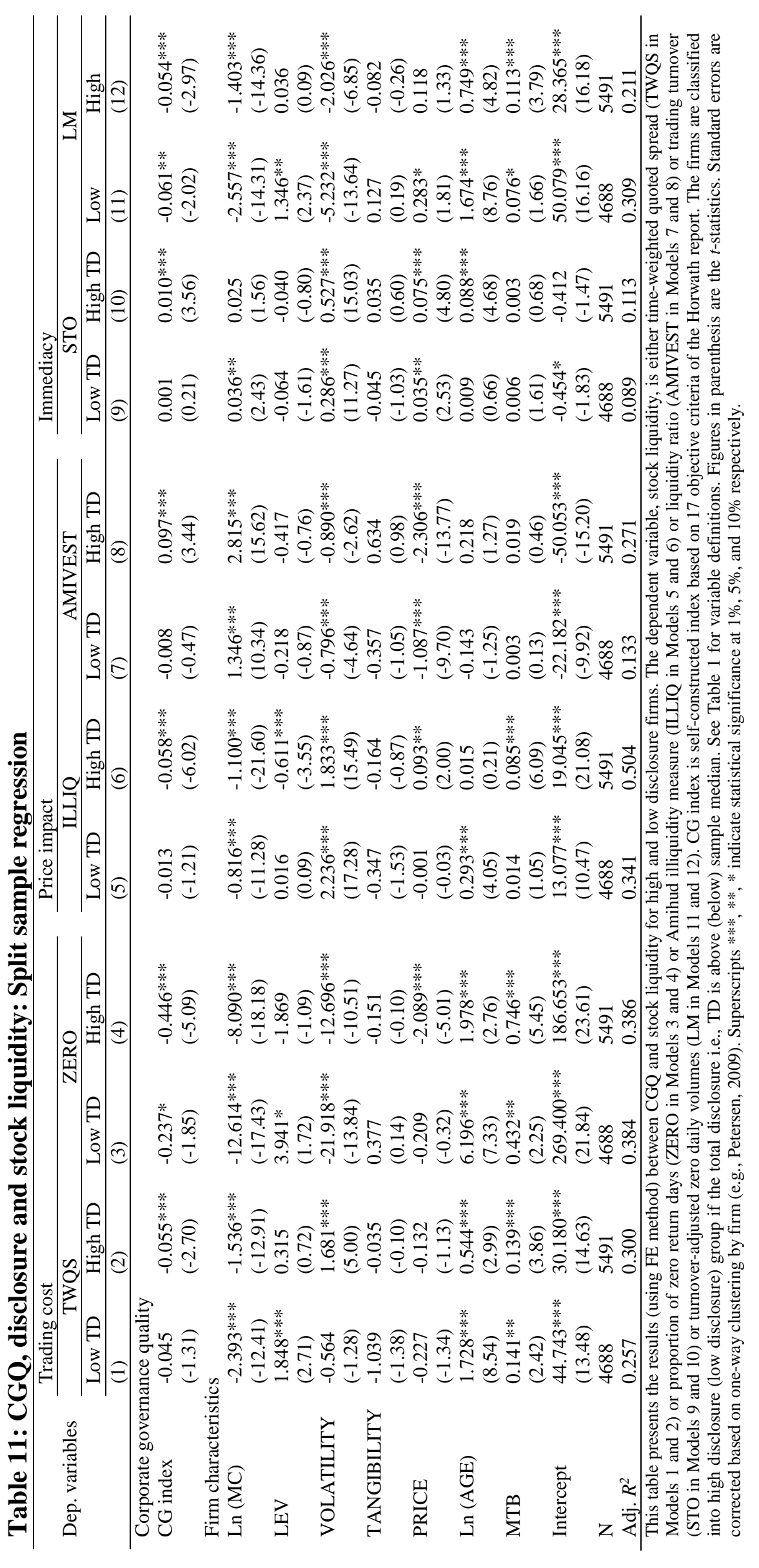


Table 12: Three-stage least squares: Reverse causality

\begin{tabular}{|c|c|c|c|c|c|c|}
\hline \multirow[b]{3}{*}{ Dep. variables } & \multicolumn{2}{|c|}{ Trading cost } & \multicolumn{2}{|c|}{ Price impact } & \multicolumn{2}{|c|}{ Immediacy } \\
\hline & $\begin{array}{l}\text { Model } 1 \\
(t \text {-stats) }\end{array}$ & $\begin{array}{l}\text { Model } 2 \\
\text { (t-stats) }\end{array}$ & $\begin{array}{l}\text { Model } 3 \\
(t \text {-stats })\end{array}$ & $\begin{array}{l}\text { Model } 4 \\
\text { (t-stats) }\end{array}$ & $\begin{array}{l}\text { Model } 5 \\
(t \text {-stats) }\end{array}$ & $\begin{array}{l}\text { Model } 6 \\
(t \text {-stats) }\end{array}$ \\
\hline & TWQS & ZERO & ILLIQ & AMIVEST & STO & LM \\
\hline \multicolumn{7}{|c|}{ Panel A: Stock liquidity (dependent variable) } \\
\hline CGQ & $\begin{array}{l}-0.055^{* * *} \\
(-20.98)\end{array}$ & $\begin{array}{l}-0.175^{* * *} \\
(-14.93)\end{array}$ & $\begin{array}{l}-0.654 * * * \\
(-8.14)\end{array}$ & $\begin{array}{l}0.226^{* * *} \\
(4.19)\end{array}$ & $\begin{array}{l}0.384^{* * *} \\
(16.12)\end{array}$ & $\begin{array}{l}-5.162^{* * *} \\
(-18.49)\end{array}$ \\
\hline Disclosure & $\begin{array}{l}-0.010 \\
(1.49)\end{array}$ & $\begin{array}{l}-0.112^{* * *} \\
(-3.75)\end{array}$ & $\begin{array}{l}-1.186^{* * *} \\
(-6.03)\end{array}$ & $\begin{array}{l}1.727 * * * \\
(13.43)\end{array}$ & $\begin{array}{l}-0.001 \\
(-0.01)\end{array}$ & $\begin{array}{l}-0.273 \\
(-0.37)\end{array}$ \\
\hline Other controls & Yes & Yes & Yes & Yes & Yes & Yes \\
\hline \multicolumn{7}{|c|}{ Panel B: Disclosure (dependent variable) } \\
\hline CGQ & $\begin{array}{l}0.208 * * * \\
(23.93)\end{array}$ & $\begin{array}{l}0.193 * * * \\
(22.95)\end{array}$ & $\begin{array}{l}0.231 * * * \\
(25.57)\end{array}$ & $\begin{array}{l}0.178 * * * \\
(20.04)\end{array}$ & $\begin{array}{l}0.184^{* * *} \\
(22.38)\end{array}$ & $\begin{array}{l}0.195 * * * \\
(23.35)\end{array}$ \\
\hline Liquidity & $\begin{array}{l}-1.826^{* * *} \\
(-4.52)\end{array}$ & $\begin{array}{l}-0.614^{* * *} \\
(-6.61)\end{array}$ & $\begin{array}{l}-0.032 \\
(-1.29)\end{array}$ & $\begin{array}{l}0.194 * * * \\
(10.15)\end{array}$ & $\begin{array}{l}0.493^{* * * *} \\
(9.81)\end{array}$ & $-0.024 * * *$ \\
\hline Other controls & Yes & Yes & Yes & Yes & Yes & Yes \\
\hline \multicolumn{7}{|c|}{ Panel C: Corporate governance (dependent variable) } \\
\hline Disclosure & $\begin{array}{l}3.280^{* * *} \\
(29.48)\end{array}$ & $\begin{array}{l}\text { 3.733*** } \\
(33.69)\end{array}$ & $\begin{array}{l}\text { 3.315*** } \\
(28.30)\end{array}$ & $\begin{array}{l}3.376 * * * \\
(27.36)\end{array}$ & $\begin{array}{l}3.916 * * * \\
(33.95)\end{array}$ & $\begin{array}{l}3.738 * * * \\
(33.54)\end{array}$ \\
\hline Liquidity & $\begin{array}{l}11.713^{* * *} \\
(5.19)\end{array}$ & $\begin{array}{l}5.701^{* * *} \\
(12.49)\end{array}$ & $\begin{array}{l}-0.483^{* * *} \\
(-6.76)\end{array}$ & $\begin{array}{l}-0.600^{* * *} \\
(-9.47)\end{array}$ & $\begin{array}{l}-3.533^{* * *} \\
(-13.11)\end{array}$ & $\begin{array}{l}0.208^{* * *} \\
(12.29)\end{array}$ \\
\hline Other controls & Yes & Yes & Yes & Yes & Yes & Yes \\
\hline $\begin{array}{l}\text { This table presents } \\
\text { which is either time } \\
\text { (ILLIQ in Model 3) } \\
\text { Model 6). The depe } \\
\text { is corporate govern } \\
\text { Figures in parenthe } \\
* * \text { * * indicate statis }\end{array}$ & sults (using $3 \mathrm{~S}$ & $\begin{array}{l}\text { EST in Model } \\
\text { is disclosure }\end{array}$ & isclosure and & liquidity. The & ). The depenc & volumes (LM \\
\hline
\end{tabular}


Table 13: Governance categories and stock liquidity: Fixed effect regression (H2a, 2b)

\begin{tabular}{|c|c|c|c|c|c|c|}
\hline \multirow[b]{3}{*}{ Dep. variables } & \multicolumn{2}{|c|}{ Trading cost } & \multicolumn{2}{|c|}{ Price impact } & \multicolumn{2}{|c|}{ Immediacy } \\
\hline & $\begin{array}{c}\text { Model } 1 \\
(t \text {-stats) }\end{array}$ & $\begin{array}{c}\text { Model } 2 \\
(t \text {-stats })\end{array}$ & $\begin{array}{c}\text { Model } 3 \\
\text { (t-stats) }\end{array}$ & $\begin{array}{c}\text { Model } 4 \\
\text { (t-stats) }\end{array}$ & $\begin{array}{c}\text { Model } 5 \\
(t \text {-stats) }\end{array}$ & $\begin{array}{c}\text { Model } 6 \\
\text { (t-stats) }\end{array}$ \\
\hline & $\begin{array}{c}\text { TWQS } \\
\text { (Clustered by } \\
\text { firm) }\end{array}$ & $\begin{array}{c}\text { ZERO } \\
\text { (Clustered by } \\
\text { firm) }\end{array}$ & $\begin{array}{c}\text { ILLIQ } \\
\text { (Clustered by } \\
\text { firm) }\end{array}$ & $\begin{array}{c}\text { AMIVEST } \\
\text { (Clustered by } \\
\text { firm) }\end{array}$ & $\begin{array}{c}\text { STO } \\
\text { (Clustered by } \\
\text { firm) }\end{array}$ & $\begin{array}{c}\text { LM } \\
\text { (Clustered by } \\
\text { firm) } \\
\end{array}$ \\
\hline \multicolumn{7}{|c|}{ Panel A: Board quality } \\
\hline Board quality & $\begin{array}{c}-0.305^{* * *} \\
(-3.40)\end{array}$ & $\begin{array}{c}-1.716^{* * *} \\
(-4.91)\end{array}$ & $\begin{array}{c}-0.115^{* * *} \\
(-3.57)\end{array}$ & $\begin{array}{c}0.050^{* *} \\
(2.49)\end{array}$ & $\begin{array}{c}0.037 * * * \\
(4.23)\end{array}$ & $\begin{array}{c}-0.313 * * * \\
(-3.96)\end{array}$ \\
\hline Other controls & Yes & Yes & Yes & Yes & Yes & Yes \\
\hline Intercept & $\begin{array}{c}47.505^{* * * *} \\
(25.07)\end{array}$ & $\begin{array}{c}263.392 * * * \\
(35.81)\end{array}$ & $\begin{array}{c}17.930 * * * \\
(23.07)\end{array}$ & $\begin{array}{c}-13.856 * * * \\
(-33.22)\end{array}$ & $\begin{array}{c}-1.010 * * * \\
(-5.12)\end{array}$ & $\begin{array}{c}47.763 * * * \\
(26.66)\end{array}$ \\
\hline Adj. $R^{2}$ & 0.390 & 0.475 & 0.475 & 0.462 & 0.180 & 0.373 \\
\hline \multicolumn{7}{|c|}{ Panel B: Audit quality } \\
\hline Audit quality & $\begin{array}{c}-0.189 * * * \\
(-4.10)\end{array}$ & $\begin{array}{c}-0.892 * * * \\
(-5.15)\end{array}$ & $\begin{array}{c}-0.067 * * * \\
(-4.38)\end{array}$ & $\begin{array}{l}-0.001 \\
(-0.12)\end{array}$ & $\begin{array}{c}0.007 * * \\
(2.34)\end{array}$ & $\begin{array}{c}-0.176^{* * * *} \\
(-4.30)\end{array}$ \\
\hline Other controls & Yes & Yes & Yes & Yes & Yes & Yes \\
\hline Intercept & $\begin{array}{c}45.992 * * * \\
(24.79)\end{array}$ & $\begin{array}{c}255.810 * * * \\
(35.17)\end{array}$ & $\begin{array}{c}17.383 * * * \\
(22.20)\end{array}$ & $\begin{array}{c}-13.783 * * * \\
(-32.69)\end{array}$ & $\begin{array}{c}-0.914 * * * \\
(-8.21)\end{array}$ & $\begin{array}{c}46.309 * * * \\
(26.35)\end{array}$ \\
\hline Adj. $R^{2}$ & 0.391 & 0.475 & 0.476 & 0.462 & 0.066 & 0.374 \\
\hline \multicolumn{7}{|c|}{ Panel C: Nomination quality } \\
\hline $\begin{array}{l}\text { Nomination } \\
\text { quality }\end{array}$ & $\begin{array}{c}-0.061 * \\
(-1.87)\end{array}$ & $\begin{array}{c}-0.683 * * * \\
(-4.01)\end{array}$ & $\begin{array}{c}-0.094 * * * \\
(-5.43)\end{array}$ & $\begin{array}{c}0.024^{* *} \\
(2.51)\end{array}$ & $\begin{array}{c}0.014 * * * \\
(3.24)\end{array}$ & $\begin{array}{c}-0.078 * * \\
(-2.16)\end{array}$ \\
\hline Other controls & Yes & Yes & Yes & Yes & Yes & Yes \\
\hline Intercept & $\begin{array}{c}46.890^{* * *} \\
(43.19)\end{array}$ & $\begin{array}{c}259.214^{* * *} \\
(35.01)\end{array}$ & $\begin{array}{c}17.548^{* * *} \\
(22.75)\end{array}$ & $\begin{array}{c}-13.726 * * * \\
(-32.85)\end{array}$ & $\begin{array}{c}-0.922 * * * \\
(-4.66)\end{array}$ & $\begin{array}{c}47.100^{* * *} \\
(26.21)\end{array}$ \\
\hline Adj. $R^{2}$ & 0.306 & 0.473 & 0.477 & 0.462 & 0.178 & 0.371 \\
\hline \multicolumn{7}{|c|}{ Panel D: Remuneration quality } \\
\hline $\begin{array}{l}\text { Remuneration } \\
\text { quality }\end{array}$ & $\begin{array}{c}-0.130 * * * \\
(-2.98)\end{array}$ & $\begin{array}{c}-0.720 * * * \\
(-3.98)\end{array}$ & $\begin{array}{c}-0.061 * * * \\
(-3.32)\end{array}$ & $\begin{array}{l}0.002 \\
(0.18)\end{array}$ & $\begin{array}{l}0.008 \\
(1.56)\end{array}$ & $\begin{array}{c}-0.126 * * * \\
(-3.13)\end{array}$ \\
\hline Other controls & Yes & Yes & Yes & Yes & Yes & Yes \\
\hline Intercept & $\begin{array}{c}46.413 * * * \\
(24.54)\end{array}$ & $\begin{array}{c}257.314 * * * \\
(34.53)\end{array}$ & $\begin{array}{c}17.463^{* * * *} \\
(22.45)\end{array}$ & $\begin{array}{c}-13.768 * * * \\
(-32.52)\end{array}$ & $\begin{array}{c}-0.916 * * * \\
(-4.54)\end{array}$ & $\begin{array}{c}46.679 * * * \\
(25.93)\end{array}$ \\
\hline Adj. $R^{2}$ & 0.389 & 0.474 & 0.475 & 0.462 & 0.177 & 0.372 \\
\hline $\begin{array}{l}\text { This table presen } \\
\text { time-weighted qu } \\
\text { Model 3) or liqu } \\
\text { Independent vari } \\
\text { mentioned in pre } \\
\text { respectively. }\end{array}$ & $\begin{array}{l}\text { results (using FE } \\
\text { spread (TWQS i } \\
\text { atio (AMIVEST } \\
\text { governance categ } \\
\text { tables. Figures in }\end{array}$ & $\begin{array}{l}\text { hod) between go } \\
\text { odel 1) or propo }\end{array}$ & $\begin{array}{l}\text { e categories and } \\
\text { zero return day } \\
\text { ver (STO in Mo } \\
\text { audit quality, n } \\
\text { tics. Superscript }\end{array}$ & $\begin{array}{l}\text { k liquidity. The } \\
\text { ERO in Model } \\
\text { 5) or turnover-ad } \\
\text { hation quality or } \\
*^{*}, * *, * \text { indicate }\end{array}$ & $\begin{array}{l}\text { dent variable, stoc } \\
\text { mihud illiquidity } \\
\text { zero daily volum } \\
\text { eration quality. } \\
\text { cal significance a }\end{array}$ & $\begin{array}{l}\text { iquidity, is eithe } \\
\text { easure (ILLIQ ir } \\
\text { LM in Model 6) } \\
\text { er controls are a } \\
\%, 5 \% \text {, and } 10 \%\end{array}$ \\
\hline
\end{tabular}


Table 14: Individual governance variables and stock liquidity: Fixed effect regression (H2a, 2b)

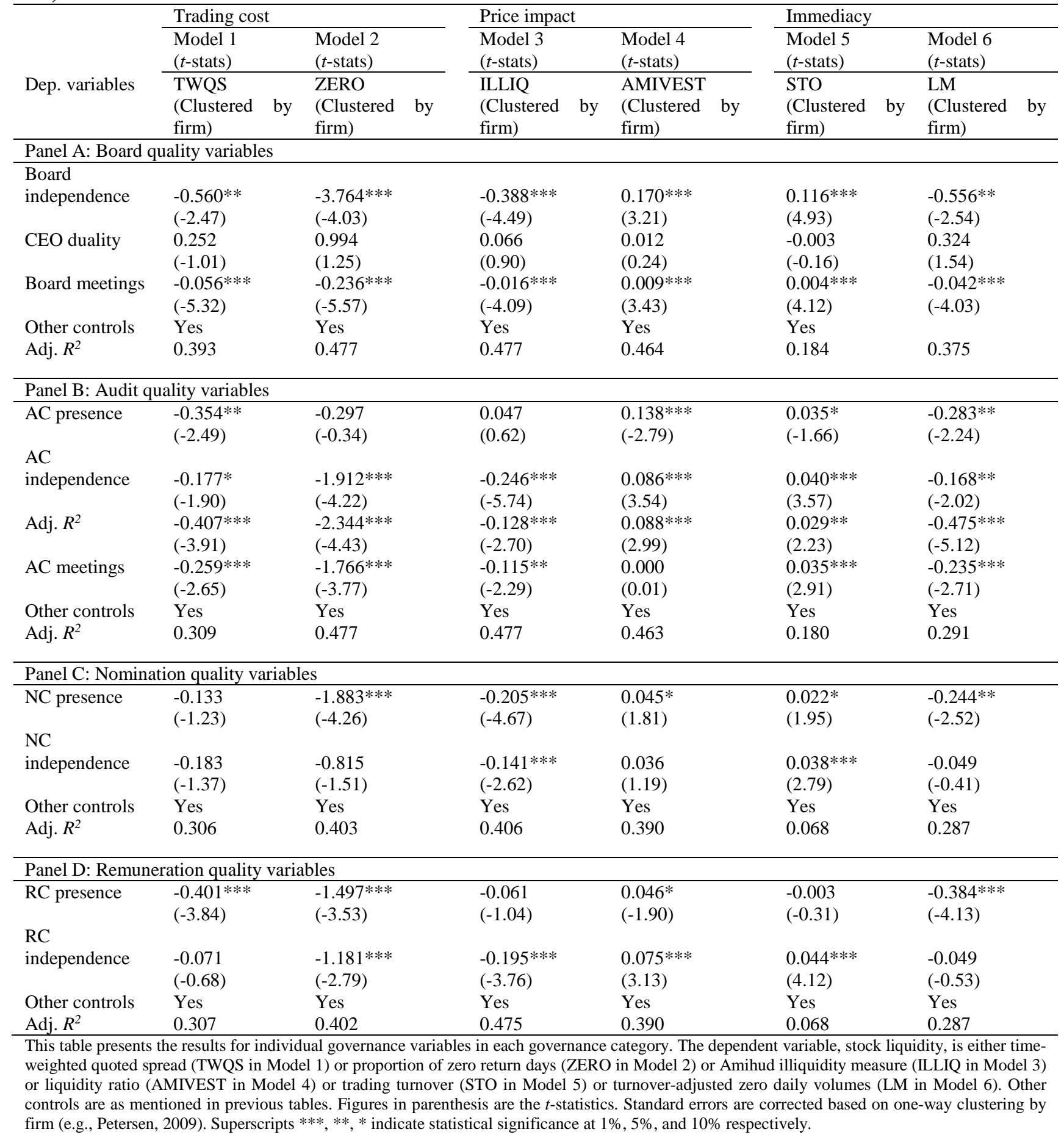


Table 15: Ownership concentration, CGQ and stock liquidity: Fixed effect regression

\begin{tabular}{|c|c|c|c|c|c|c|}
\hline \multirow[b]{3}{*}{ Dep. variables } & \multicolumn{2}{|l|}{ Trading cost } & \multicolumn{2}{|l|}{ Price impact } & \multicolumn{2}{|l|}{ Immediacy } \\
\hline & $\begin{array}{l}\text { Model } 1 \\
\text { ( } t \text {-stats) }\end{array}$ & $\begin{array}{l}\text { Model } 2 \\
(t \text {-stats) }\end{array}$ & $\begin{array}{l}\text { Model } 3 \\
\text { (t-stats) }\end{array}$ & $\begin{array}{l}\text { Model } 4 \\
\text { (t-stats) }\end{array}$ & $\begin{array}{l}\text { Model } 5 \\
(t \text {-stats) }\end{array}$ & $\begin{array}{l}\text { Model } 6 \\
\text { (t-stats) }\end{array}$ \\
\hline & $\begin{array}{l}\text { TWQS } \\
\text { (Clustered by } \\
\text { firm) }\end{array}$ & $\begin{array}{l}\text { ZERO } \\
\text { (Clustered by } \\
\text { firm) }\end{array}$ & $\begin{array}{l}\text { ILLIQ } \\
\text { (Clustered by } \\
\text { firm) }\end{array}$ & $\begin{array}{l}\text { AMIVEST } \\
\text { (Clustered by } \\
\text { firm) }\end{array}$ & $\begin{array}{l}\text { STO } \\
\text { (Clustered by } \\
\text { firm) }\end{array}$ & $\begin{array}{l}\text { LM } \\
\text { (Clustered by } \\
\text { firm) }\end{array}$ \\
\hline \multicolumn{7}{|c|}{ Corporate governance quality } \\
\hline CG index & $\begin{array}{l}-0.084 * * * \\
(-4.28)\end{array}$ & $\begin{array}{l}-0.478 * * * \\
(-6.18)\end{array}$ & $\begin{array}{l}-0.042^{* * *} \\
(-5.67)\end{array}$ & $\begin{array}{l}0.010^{* *} \\
(2.22)\end{array}$ & $\begin{array}{l}0.005 * * * \\
(2.82)\end{array}$ & $\begin{array}{l}-0.082^{* * *} \\
(-4.69)\end{array}$ \\
\hline OC index & $\begin{array}{l}0.364 * * * \\
(6.30)\end{array}$ & $\begin{array}{l}2.136^{* * *} \\
(9.70)\end{array}$ & $\begin{array}{l}0.176^{* * *} \\
(8.44)\end{array}$ & $\begin{array}{l}-0.135^{* * *} \\
(-10.57)\end{array}$ & $\begin{array}{l}-0.068 * * * \\
(-12.08)\end{array}$ & $\begin{array}{l}0.442^{* * *} \\
(8.26)\end{array}$ \\
\hline \multicolumn{7}{|c|}{ Firm characteristics } \\
\hline $\operatorname{Ln}(\mathrm{MC})$ & $\begin{array}{l}-2.303 * * * \\
(-21.72)\end{array}$ & $\begin{array}{l}-11.550 * * * \\
(-27.79)\end{array}$ & $\begin{array}{l}-1.035^{* * *} \\
(-24.15)\end{array}$ & $\begin{array}{l}0.873 * * * \\
(36.62)\end{array}$ & $\begin{array}{l}0.053 * * * \\
(4.94)\end{array}$ & $\begin{array}{l}-2.266 * * * \\
(-22.63)\end{array}$ \\
\hline TLTA & $\begin{array}{l}1.247^{* * *} \\
(3.01)\end{array}$ & $\begin{array}{l}1.755 \\
(1.21)\end{array}$ & $\begin{array}{l}-0.345^{* * *} \\
(-2.73)\end{array}$ & $\begin{array}{l}-0.259 * * * \\
(-3.22)\end{array}$ & $\begin{array}{l}-0.013 \\
(-0.43)\end{array}$ & $\begin{array}{l}0.873^{* *} \\
(2.37)\end{array}$ \\
\hline VOLATILITY & $\begin{array}{l}-1.725^{* * * *} \\
(-5.33)\end{array}$ & $\begin{array}{l}-21.785 * * * \\
(-19.75)\end{array}$ & $\begin{array}{l}1.945^{* * *} \\
(18.93)\end{array}$ & $\begin{array}{l}-0.616^{* * *} \\
(-11.07)\end{array}$ & $\begin{array}{l}0.537 * * * \\
(21.22)\end{array}$ & $\begin{array}{l}-5.329 * * * \\
(-18.48)\end{array}$ \\
\hline TANGIBILITY & $\begin{array}{l}-0.694 * \\
(-1.86)\end{array}$ & $\begin{array}{l}-0.524 \\
(-0.36)\end{array}$ & $\begin{array}{l}-0.316^{* *} \\
(-2.11)\end{array}$ & $\begin{array}{l}-0.065 \\
(-0.76)\end{array}$ & $\begin{array}{l}0.040 \\
(1.07)\end{array}$ & $\begin{array}{l}-0.168 \\
(-0.50)\end{array}$ \\
\hline PRICE & $\begin{array}{l}0.003 \\
(0.03)\end{array}$ & $\begin{array}{l}-0.364 \\
(-0.94)\end{array}$ & $\begin{array}{l}0.084 * * \\
(2.27)\end{array}$ & $\begin{array}{l}-0.700 * * * \\
(-30.88)\end{array}$ & $\begin{array}{l}0.053 * * * \\
(5.16)\end{array}$ & $\begin{array}{l}0.370 * * * \\
(4.02)\end{array}$ \\
\hline Ln (AGE) & $\begin{array}{l}0.076 \\
(0.43)\end{array}$ & $\begin{array}{l}0.264 \\
(0.35)\end{array}$ & $\begin{array}{l}0.089 \\
(1.18)\end{array}$ & $\begin{array}{l}0.073 * * \\
(2.32)\end{array}$ & $\begin{array}{l}0.050 * * * \\
(2.96)\end{array}$ & $\begin{array}{l}0.330^{*} \\
(1.91)\end{array}$ \\
\hline MTB & $\begin{array}{l}0.213^{* * *} \\
(6.83)\end{array}$ & $\begin{array}{l}0.842^{* * * *} \\
(7.31)\end{array}$ & $\begin{array}{l}0.070^{* * * *} \\
(6.90)\end{array}$ & $\begin{array}{l}0.014 * * \\
(2.27)\end{array}$ & $\begin{array}{l}-0.005 * \\
(-1.70)\end{array}$ & $\begin{array}{l}0.162 * * * \\
(6.18)\end{array}$ \\
\hline $\begin{array}{l}\text { Industry effect } \\
\text { (IND) }\end{array}$ & No & No & No & No & No & No \\
\hline Year effect & Yes & Yes & Yes & Yes & Yes & Yes \\
\hline Firm fixed & Yes & Yes & Yes & Yes & Yes & Yes \\
\hline Intercept & $\begin{array}{l}45.951 * * * \\
(24.73)\end{array}$ & $\begin{array}{l}254.580 * * * \\
(35.12)\end{array}$ & $\begin{array}{l}17.217 * * * \\
(22.94)\end{array}$ & $\begin{array}{l}-13.544 * * * \\
(-33.23)\end{array}$ & $\begin{array}{l}-0.861^{* * * *} \\
(-4.59)\end{array}$ & $\begin{array}{l}46.188 * * * \\
(26.10)\end{array}$ \\
\hline $\begin{array}{l}\text { Model fits: } \\
\text { Adj. } R^{2} \\
\text { F-statistics }\end{array}$ & 0.397 & 0.487 & 0.485 & 0.436 & 0.204 & 0.385 \\
\hline $\mathrm{N}$ & 10179 & 10179 & 10179 & 10179 & 10179 & 10179 \\
\hline No. of firms & 1207 & 1207 & 1207 & 1207 & 1207 & 1207 \\
\hline
\end{tabular}

This table presents the results of firm fixed effect regression between corporate governance, ownership structure and stock liquidity. The dependent variable SLQ is either time-weighted quoted spread (TWQS in Model 1) or proportion of zero return days (ZERO in Model 2) or Amihud illiquidity measure (ILLIQ in Model 3) or liquidity ratio (AMIVEST in Model 4) or trading turnover (STO in Model 5) or turnover-adjusted zero daily volumes (LM in Model 6). CG index is self-constructed index based on 17 objective criteria of the Horwath report; OC index is based on four variables namely percentage of shares held by TOP20 (above median 1), block holders (above median 1), and CEO (above median 1), and the presence of one or more directors with substantial shareholdings. CG index is self-constructed index based on 17 objective criteria of the Horwath report. See Table 1 for variable definitions. Figures in parenthesis are the t-statistics. Superscripts ***, **, * indicate statistical significance at $1 \%, 5 \%$, and $10 \%$ respectively. 
Table 16: CGQ and stock liquidity: Additional controls for information asymmetry

\begin{tabular}{|c|c|c|c|c|c|c|}
\hline \multirow[b]{3}{*}{ Dep. Var. } & \multicolumn{2}{|l|}{ Trading cost } & \multicolumn{2}{|l|}{ Price impact } & \multicolumn{2}{|l|}{ Immediacy } \\
\hline & $\begin{array}{l}\text { Model } 1 \\
\text { (t-stats) }\end{array}$ & $\begin{array}{l}\text { Model } 2 \\
\text { (t-stats) }\end{array}$ & $\begin{array}{l}\text { Model } 3 \\
\text { (t-stats) }\end{array}$ & $\begin{array}{l}\text { Model } 4 \\
\text { (t-stats) }\end{array}$ & $\begin{array}{l}\text { Model } 5 \\
\text { (t-stats) }\end{array}$ & $\begin{array}{l}\text { Model } 6 \\
\text { (t-stats) }\end{array}$ \\
\hline & $\begin{array}{l}\text { TWQS } \\
\text { (Clustered by } \\
\text { firm) }\end{array}$ & $\begin{array}{l}\text { ZERO } \\
\text { (Clustered by } \\
\text { firm) }\end{array}$ & $\begin{array}{l}\text { ILLIQ } \\
\text { (Clustered by } \\
\text { firm) }\end{array}$ & $\begin{array}{l}\text { LR } \\
\text { (Clustered by } \\
\text { firm) }\end{array}$ & $\begin{array}{l}\text { TO } \\
\text { (Clustered by } \\
\text { firm) }\end{array}$ & $\begin{array}{l}\text { LM } \\
\text { (Clustered by } \\
\text { firm) }\end{array}$ \\
\hline CG index & $\begin{array}{l}-0.085^{* * *} \\
(-3.99)\end{array}$ & $\begin{array}{l}-0.480 * * * \\
(-5.77)\end{array}$ & $\begin{array}{l}-0.052^{* * *} \\
(-6.25)\end{array}$ & $\begin{array}{l}0.011^{* *} \\
(2.20)\end{array}$ & $\begin{array}{l}0.009 * * * \\
(3.85)\end{array}$ & $\begin{array}{l}-0.079 * * * \\
(-4.10)\end{array}$ \\
\hline Additional & ntrols & & & & & \\
\hline BIG4 & $\begin{array}{l}-0.516 * * \\
(-2.48)\end{array}$ & $\begin{array}{l}-3.232 * * * \\
(-4.01)\end{array}$ & $\begin{array}{l}-0.046 \\
(-0.59)\end{array}$ & $\begin{array}{l}-0.035 \\
(-0.78)\end{array}$ & $\begin{array}{l}0.002 \\
(0.14)\end{array}$ & $\begin{array}{l}-0.768 * * * \\
(-3.98)\end{array}$ \\
\hline R\&D & $\begin{array}{l}-0.014 \\
(-0.40)\end{array}$ & $\begin{array}{l}-0.054 \\
(-0.43)\end{array}$ & $\begin{array}{l}0.012 \\
(1.08)\end{array}$ & $\begin{array}{l}-0.001 \\
(-0.08)\end{array}$ & $\begin{array}{l}-0.000 \\
(-0.09)\end{array}$ & $\begin{array}{l}-0.047 \\
(-1.63)\end{array}$ \\
\hline CEOSh & $\begin{array}{l}0.328 \\
(0.44)\end{array}$ & $\begin{array}{l}8.586 * * * \\
(3.26)\end{array}$ & $\begin{array}{l}0.464^{* *} \\
(2.07)\end{array}$ & $\begin{array}{l}-0.404^{* * *} \\
(-3.31)\end{array}$ & $\begin{array}{l}-0.135 * * * \\
(-3.09)\end{array}$ & $\begin{array}{l}1.489 * * \\
(2.49)\end{array}$ \\
\hline $\begin{array}{l}\text { Other } \\
\text { controls }\end{array}$ & Yes & Yes & Yes & Yes & Yes & Yes \\
\hline Constant & $\begin{array}{l}44.445^{* * * *} \\
(21.77)\end{array}$ & $\begin{array}{l}246.331 * * * \\
(31.86)\end{array}$ & $\begin{array}{l}16.644^{* * * *} \\
(19.83)\end{array}$ & $\begin{array}{l}-13.444 * * * \\
(-29.76)\end{array}$ & $\begin{array}{l}-0.810 * * * \\
(-3.72)\end{array}$ & $\begin{array}{l}44.713^{* * * *} \\
(23.14)\end{array}$ \\
\hline $\begin{array}{l}\text { Adj. R2 } \\
\mathrm{N}\end{array}$ & $\begin{array}{l}0.398 \\
8920\end{array}$ & $\begin{array}{l}0.492 \\
8920\end{array}$ & $\begin{array}{l}0.495 \\
8920\end{array}$ & $\begin{array}{l}0.474 \\
8920\end{array}$ & $\begin{array}{l}0.188 \\
8920\end{array}$ & $\begin{array}{l}0.384 \\
8920\end{array}$ \\
\hline
\end{tabular}

This table presents the results (using FE method) between CGQ and stock liquidity by including more control variables for information asymmetry. The dependent variable is either time-weighted quoted spread (TWQS in Model 1) or proportion of zero return days (ZERO in Model 2) or Amihud illiquidity measure (ILLIQ in Model 3) or liquidity ratio (AMIVEST in Model 4) or trading turnover (STO in Model 5) or turnover-adjusted zero daily volumes (LM in Model 6). CG index is self-constructed index based on 17 objective criteria of the Horwath report. Big4 is a dummy variable that takes a value ' 1 ' if a firm is audited by a Big 4 Audit firm and ' 0 ' otherwise. R\&D is a ratio of R\&D expenditure divided by annual sales. CEOSh is a percentage of the firm's outstanding shares held by the CEO. Other controls are as mentioned in previous tables. Figures in parenthesis are the t-statistics. Superscripts ***, **, * indicate statistical significance at $1 \%, 5 \%$, and $10 \%$ respectively. 
Table 17: CGQ, information asymmetry and stock liquidity: Split sample regression

\begin{tabular}{lllllll}
\hline \multicolumn{2}{l}{ Panel A: Subsample analysis based on BIG4 } & \multicolumn{2}{l}{} \\
\hline & \multicolumn{2}{l}{ Trading cost (TWQS) } & Price impact (ILLIQ) & \multicolumn{2}{l}{ Immediacy (LM) } \\
\cline { 2 - 7 } & Low & High & Low & High & Low & High \\
\cline { 2 - 7 } & $(1)$ & $(2)$ & $(3)$ & $(4)$ & $(5)$ & $(6)$ \\
\hline CG index & $-0.089^{* * *}$ & -0.045 & $-0.052^{* * *}$ & $-0.026^{* *}$ & $-0.088^{* * *}$ & -0.053 \\
& $(-3.64)$ & $(-1.22)$ & $(-4.94)$ & $(-2.10)$ & $(-3.63)$ & $(-1.60)$ \\
Additional controls & Yes & Yes & Yes & Yes & Yes & Yes \\
Other controls & Yes & Yes & Yes & Yes & Yes & Yes \\
Constant & $35.886^{* * *}$ & $49.843^{* * *}$ & $19.062^{* * *}$ & $14.332^{* * *}$ & $35.239^{* * *}$ & $50.280^{* * *}$ \\
& $(12.76)$ & $(15.74)$ & $(14.40)$ & $(12.92)$ & $(12.21)$ & $(18.53)$ \\
Adj. R2 & 0.348 & 0.415 & 0.481 & 0.488 & 0.292 & 0.436 \\
N & 5313 & 3607 & 5313 & 3607 & 5313 & 3607 \\
\hline
\end{tabular}

Panel B: Subsample analysis based on R\&D

\begin{tabular}{|c|c|c|c|c|c|c|}
\hline & \multicolumn{2}{|c|}{ Trading cost (TWQS) } & \multicolumn{2}{|c|}{ Price impact (ILLIQ) } & \multicolumn{2}{|c|}{ Immediacy (LM) } \\
\hline & Low & High & Low & High & Low & High \\
\hline & $(1)$ & $(2)$ & (3) & (4) & (5) & (6) \\
\hline CG index & $\begin{array}{l}-0.093 * * * \\
(-3.88)\end{array}$ & $\begin{array}{l}-0.019 \\
(-0.44)\end{array}$ & $\begin{array}{l}-0.058^{* * *} \\
(-6.40)\end{array}$ & $\begin{array}{l}-0.012 \\
(-0.51)\end{array}$ & $\begin{array}{l}-0.081 * * * \\
(-3.77)\end{array}$ & $\begin{array}{l}-0.048 \\
(-1.11)\end{array}$ \\
\hline Additional controls & Yes & Yes & Yes & Yes & Yes & Yes \\
\hline Other controls & Yes & Yes & Yes & Yes & Yes & Yes \\
\hline Constant & $\begin{array}{l}45.001 * * * \\
(20.14)\end{array}$ & $\begin{array}{l}35.605 * * * \\
(4.56)\end{array}$ & $\begin{array}{l}16.113^{* * *} \\
(18.00)\end{array}$ & $\begin{array}{l}20.369 * * * \\
(6.64)\end{array}$ & $\begin{array}{l}45.112^{* * * *} \\
(21.80)\end{array}$ & $\begin{array}{l}33.496 * * * \\
(5.88)\end{array}$ \\
\hline Adj. R2 & 0.402 & 0.351 & 0.511 & 0.380 & 0.392 & 0.306 \\
\hline $\mathrm{N}$ & 7581 & 1339 & 7581 & 1339 & 7581 & 1339 \\
\hline \multicolumn{7}{|c|}{ Panel C: Subsample analysis based on CEOSh } \\
\hline & \multicolumn{2}{|c|}{ Trading cost (TWQS) } & \multicolumn{2}{|c|}{ Price impact (ILLIQ) } & \multicolumn{2}{|c|}{ Immediacy (LM) } \\
\hline & Low & High & Low & High & Low & High \\
\hline & $(1)$ & $(2)$ & (3) & $(4)$ & (5) & $(6)$ \\
\hline CG index & $\begin{array}{l}-0.082 * \\
(-1.83)\end{array}$ & $\begin{array}{l}-0.067 \\
(-1.42)\end{array}$ & $\begin{array}{l}-0.052 * * * \\
(-3.26)\end{array}$ & $\begin{array}{l}-0.026 * \\
(-1.73)\end{array}$ & $\begin{array}{l}-0.078^{* *} \\
(-2.02)\end{array}$ & $\begin{array}{l}-0.051 \\
(-1.21)\end{array}$ \\
\hline Additional controls & Yes & Yes & Yes & Yes & Yes & Yes \\
\hline Other controls & Yes & Yes & Yes & Yes & Yes & Yes \\
\hline Constant & $\begin{array}{l}46.526 * * * \\
(11.80)\end{array}$ & $\begin{array}{l}50.449 * * * \\
(10.85)\end{array}$ & $\begin{array}{l}15.011^{* * * *} \\
(8.42)\end{array}$ & $\begin{array}{l}16.840 * * * \\
(8.07)\end{array}$ & $\begin{array}{l}45.218^{* * *} \\
(10.92)\end{array}$ & $\begin{array}{l}54.332^{* * * *} \\
(12.37)\end{array}$ \\
\hline Observations & 2231 & 2323 & 2231 & 2323 & 2231 & 2323 \\
\hline Adj. R2 & 0.387 & 0.406 & 0.474 & 0.390 & 0.417 & 0.400 \\
\hline
\end{tabular}

This table presents the results (using FE method) between CGQ and stock liquidity for high and low information asymmetry firms. The dependent variable stock liquidity is either time-weighted quoted spread (TWQS in Models 1 and 2) or Amihud illiquidity measure (ILLIQ in Models 3 and 4) or turnover-adjusted zero daily volumes (LM in Models 4 and 5). CG index is self-constructed index based on 17 objective criteria of the Horwath report. The firms are classified into low information asymmetry (high information asymmetry group if a firm avails (does not avail) the auditing service from Big4 audit firm; a firm does not (does) have R\&D expenditure, and a firm has low (high) CEO shareholdings. See Table 1 for the definition of other variables. Figures in parenthesis are the t-statistics. Standard errors are corrected based on one-way clustering by firm (e.g., Petersen, 2009). Superscripts ***,**, * indicate statistical significance at $1 \%, 5 \%$, and $10 \%$ respectively. 
Table 18: CGQ, timeliness of price discovery, and stock liquidity

\begin{tabular}{|c|c|c|c|c|}
\hline & \multirow{2}{*}{$\begin{array}{l}\text { Panel A: CGQ and } \\
\text { timeliness } \\
\text { Model 1 } \\
\text { (t-stats) } \\
\text { TIMFI INFSS }\end{array}$} & \multicolumn{3}{|c|}{ Panel B: Timeliness and stock liquidity } \\
\hline & & $\begin{array}{l}\text { Model } 2 \\
\text { (t-stats) }\end{array}$ & $\begin{array}{l}\text { Model } 3 \\
\text { (t-stats) }\end{array}$ & $\begin{array}{l}\text { Model } 4 \\
\text { (t-stats) }\end{array}$ \\
\hline & $\begin{array}{l}\text { TIMELINESS } \\
\text { (Clustered by firm) }\end{array}$ & $\begin{array}{l}\text { TWQS } \\
\text { (Clustered by } \\
\text { firm) }\end{array}$ & $\begin{array}{l}\text { ILLIQ } \\
\text { (Clustered by } \\
\text { firm) }\end{array}$ & $\begin{array}{l}\text { LM } \\
\text { (Clustered by } \\
\text { firm) }\end{array}$ \\
\hline CG index & $\begin{array}{l}-0.003^{* * *} \\
(-3.87)\end{array}$ & & & \\
\hline TIMELINESS & & $\begin{array}{l}1.804 * * * \\
(10.67)\end{array}$ & $\begin{array}{l}1.666^{* * * *} \\
(11.03)\end{array}$ & $\begin{array}{l}0.339 * \\
(1.66)\end{array}$ \\
\hline $\begin{array}{l}\text { Additional } \\
\text { controls }\end{array}$ & Yes & Yes & Yes & Yes \\
\hline Other controls & Yes & Yes & Yes & Yes \\
\hline Constant & $\begin{array}{l}0.760 * * * \\
(20.60)\end{array}$ & $\begin{array}{l}26.136 * * * \\
(56.05)\end{array}$ & $\begin{array}{l}0.703^{* * * *} \\
(5.27)\end{array}$ & $\begin{array}{l}2.691 * * * \\
(14.87)\end{array}$ \\
\hline Adj. R2 & 0.133 & 0.514 & 0.457 & 0.154 \\
\hline $\mathrm{N}$ & 5463 & 5463 & 5463 & 5463 \\
\hline
\end{tabular}

